\title{
KGB rezervo problemos sprendimas ir/ar nacionalinio saugumo interesai
}

\begin{abstract}
KGB Lietuvoje oficialiai nustojo egzistuoti $1991 \mathrm{~m}$. spalio 1 d., bet prie šios komunistinio režimo slaptosios tarnybos palikimo vertinimo nuolat sugrižžtama. Visuomenės atminties tyrinètojai pastebi, kad joje ilgiausiai išlieka tie praeities aspektai, kurie kokiu nors būdu tebesitęsia dabartyje, bei momentai, susiję su neišspręstomis skriaudos, kaltès, atsakomybès ir panašiomis problemomis. Straipsnyje iškeltas tikslas apžvelgti požiūrį i KGB palikimą, visuomenès ir politikų santykị su iškilusiu vienu KGB palikimo aspektu - vadinamuoju „KGB rezervu“. Politinių šalies sluoksniu santyki galima pavadinti nekonstruktyviu ir iš dalies amnezija bei reliatyvizmu pagrịstą, tad analizuojami méginimai pasirinkti efektyvesnes veiksmu strategijas i „,KGB rezervo" skandala patekus už Lietuvos nacionalinį sauguma atsakingu instituciju vadovams. Santykio su KGB permąstymas pasuktas parlamentinio tyrimo ir teisés aktų tobulinimo keliu. Ir nors paviešintoje aukštu valstybès pareigūnu, KGB rezervistu, praeityje, teisiškai žiūrint, neaptikta jokio "sąmoningo“ bendradarbiavimo pèdsa$\mathrm{ku}$, tačiau nemaža visuomenės dalis to ar kito asmens praeities susipynimo su represiju ir teroro organizacijos KGB veikla nepateisina.
\end{abstract}

\section{Ivadas}

Pototalitarinėms visuomenėms iškyla nelengvas uždavinys - suderinti įvairiu grupių atmintį taip, kad visuomenèje galètų be įtampos gyventi bei kurti bendrą ateitį ir režimo aukos, ir buvę represijų organizatoriai bei vykdytojai. Atkūrus Lietuvos Respublikos nepriklausomybę, sovietinio Valstybės saugumo komiteto (toliau - KGB; liet. - VSK) ne kartą Lietuvos teisės aktuose įvertinta kaip represinė okupacinės valdžios institucija (Konstitucinio Teismo $1999 \mathrm{~m}$. kovo 4 d. ir $2000 \mathrm{~m}$. vasario $10 \mathrm{~d}$. nutarimai). Todèl asmens priklausymas KGB ar bet koks kitas slaptas ar neviešas bendravimas (ar bendradarbiavimas) su KGB visuomenëje gali būti vertinamas neigiamai, kaip asmens garbę ir orumą žeminanti aplinkybè. Aukštiems politinès valdžios pareigūnams žinomų duomenų apie Seimo, Užsienio reikalų ministerijos (toliau - URM) ir Valstybės saugumo departamento (toliau - VSD) (ar kitų instituciju) vadovu, kurie vykdo svarbias funkcijas užtikrinant nacionalinį saugumą, priklausomybę „,KGB re-

\footnotetext{
* Doc. dr. Aroydas Anušauskas - Lietuvos gyventoju genocido ir rezistencijos tyrimo centro Genocido ir rezistencijos tyrimo departamento direktorius ir Vilniaus universiteto Istorijos fakulteto Naujosios istorijos katedros docentas. Adresas: Didžioji g. 17/1, 01128 Vilnius, tel. 2791036, el. paštas: arvydas@genocid.lt.
} 
zervui“" slëpimas nuo visuomenès, kaip ir tokių duomenu paviešinimas, galëjo sukelti grèsmę nacionaliniam saugumui.

Tai tik patvirtina, kad po simbolinių veiksmų (ivvairių sovietinès praeities aspektu pasmerkimo mitinguose ir žiniasklaidoje, paminklų nuvertimo, gatvių pavadinimų pakeitimo, sovietmečiu draustų simbolių ir institucijų atkūrimo, represuotujų reabilitavimo ir pan.) turëjo sekti ir nuoseklus sovietinio saugumo palikimo įvertinimas. Juk radikalių lūžiu sąlygomis socialinės struktūros ir praktikos turi nemaža tęstinių aspektų. Santykių su KGB (ar Lietuvos komunistu partija) suformuoto mentaliteto, elgsenos modeliu negalima staiga pakeisti ar atsikratyti. Bet visa tai būtina įvertinti ne tik permąstant praeiti, bet ir nustatant atitinkamas elgesio su KGB palikimu strategijas.

Bet vargu ar atsakomybès klausimo apribojimas tik vienos struktūros - KGB veikla visiškai išsprendžia atsakomybės už sovietmečio blogybes klausima,-ji reikètų svarstyti išsamiau. Grupès ar struktūros narių kolektyvinès atsakomybės prisièmimas laikomas konstruktyvia strategija, nes ji padeda suvokti ir kritiškai įvertinti savo grupės padarytas niekšybes, nors jose nedalyvauta asmeniškai, ir siekti, kad tai nesikartotų (restitucija kolektyvinëje atsakomybëje dažniausiai simbolinè, moralinė-atsiprašymas, îvardijimas ir pan.). Atvirumas ir "tiesos sakymas“ ne supriešintų visuomenę, o atvirkščiai, padètų greičiau pasiekti reikalingą sutarimą. Bet „,KGB rezervistu“" problema (skandalas) parode, kad tuo keliu žengti yra kur kas sunkiau. Straipsnyje iškeltas tikslas apžvelgti požiūrįi KGB palikimą, visuomenès ir politikų santykį su iškilusiu vienu KGB palikimo aspektu - vadinamuoju „KGB rezervu“. Analizuojamos pasirinktos veiksmų strategijos i „,KGB rezervo“ skandalą patekus už Lietuvos nacionalinį saugumą atsakingų institucijų vadovams.

\section{KGB ,,palikimas“ ir „,KGB rezervo“ samprata}

\subsection{KGB palikimo vertinimo problema}

Daugelyje buvusių socialistinių valstybių informacija iš slaptujų tarnybu archyvų nutekédavo ir patekdavo į spaudą. $1990 \mathrm{~m}$. pradžioje pirmą kartą Lietuvoje paméginta pasinaudoti KGB korta, „,Respublikos" redakcijai siųstame anoniminiame laiške bendradarbiavimu su sovietiniu saugumu apkaltinus kelis Sąjūdžio aktyvistus. Atkūrus Lietuvos nepriklausomybę, $1990 \mathrm{~m}$. kovo 23 d. buvo priimtas Vyriausybės nutarimas, kuriuo KGB ịpareigota nutraukti savo veiklą. Esminis skirtumas nuo kitų Rytų Europos valstybių buvo tas, kad sovietinè saugumo struktūra paskelbta esanti už įstatymo ribuz, t. y. svetimos valstybės institucija Lietuvos Respublikos teritorijoje. Lietuvos Aukščiausioji Taryba 1990 m. kovo 27 d. neturėdama kitu galimybių tik simboliškai tam užkirto kelią, pareiškusi, kad agentai, ,, atsisakę palaikyti tolesnius ryšius su TSRS VSK, nepatirs nei moraliniu, nei teisiniu, nei jokių kitokių Respublikos valdžios persekiojimų “ ${ }^{\prime 1}$. Bet

${ }_{1}^{1}$ „Lietuvos Respublikos Aukščiausiosios Tarybos 1990 m. kovo 27 d. pareiškimas, Lietuvos Respublikos Aukščiausiosios Tarybos ir Aukščiausiosios Tarybos Prezidiumo dokumentu rinkinys I, Vilnius, 1991, p. 346. 
agentūrinis KGB tinklas, nors ir stipriai aptirpęs (agentų skaičius, 1991 m. sausio $1 \mathrm{~d}$. duomenimis, sumažèjo nuo 6377 iki 5598) ir beveik netekęs galimybès atsinaujinti (1989 m. KGB Lietuvoje užverbavo 358 žm.,1990 m. - 117 naujų agentu, $1991 \mathrm{~m} .-33)^{2}$, tebeliko svaria vidaus politikos problema. KGB palikimas pakankamai stipriai tebeveikè Lietuvos visuomenę. Vien tik per SSSR specialiuju tarnybų agentūrinį tinklą perëjo apie 100 tūkst. Lietuvos gyventoju, iš kurių 19561990 m.- apie 50 tūkst. žm³ . Ne mažiau žmonių buvo susiję su KGB ir kitais saitais - kaip patikimi asmenys (dèl savo einamų pareigu teikę KGB reikalingą pagalbą) arba kaip komunistinės valdžiusiosios nomenklatūros atstovai (sudarę KGB veiklai tinkamas sąlygas ir naudojęsi KGB galia savo valdžiai išlaikyti ir stiprinti). 1990-1991 m. KGB visa savo veikla - nuo slaptos informacijos rinkimo, netiesioginio parankių politikų bei organizacijų rèmimo, nuoseklių Lietuvos nepriklausomybės šalininkų šmeižimo ir skaldymo iki Lietuvai nepalankios informacijos skleidimo tarptautinėse organizacijose ir Vakarų šalyse - mėgino iš pradžių sutrukdyti Lietuvos valstybẻs atkūrimui, vẻliau - jos tarptautiniam pripažinimui. Bet iš kitos pusės, KGB galimybės buvo gerokai apribotos netekus didelès dalies informacijos surinkimo galimybių (atjungus telefoninių pokalbiu pasiklausymo techninę irangą, netekus legalaus priëjimo prie Vidaus reikalų ministerijos duomenu baziu), netekus galimybiu veikti per buvusias priedangos organizacijas ir kontroliuoti ryšiu su kitų šaliu piliečiais bei netekus baudžiamuju svertų. Tik nuo $1991 \mathrm{~m}$. rugpjūčio $24 \mathrm{~d}$. KGB problemą buvo įmanoma pradèti radikaliai spręsti. Sudaryta speciali komisija KGB turtui perimti ir jo veiklai Lietuvoje tirti ${ }^{4}$. KGB struktūra turèjo būti likviduota per du mènesius.

Pradejus perimti KGB archyvus ir prièmus pirmą specialų įstatymą „,Dèl deputatu, įtariamų sąmoningu bendradarbiavimu su kitų valstybių specialiosiomis tarnybomis, mandato patikrinimo ${ }^{\prime 5}$, prasidejo dokumentų dingimo skandalai, prieštaringai vertinami „Voratinklio" straipsniai ${ }^{6}$. Anot tuometinès ko-

\footnotetext{
${ }^{2}$ Endriukaitis A., "Voratinklis", Lietuvos aidas, $1992 \mathrm{~m}$. sausio $16 \mathrm{~d}$.

${ }^{3}$ KGB specialistų teigimu, visoje agentūroje įtakos agentų buvo 5-10\%. Penktadalis (15-20\%) buvo vadinamieji agentai „,korespondentai“, t. y. pagal KGB užduotis ieškantys patvirtinančios informacijos, patikslinantys gautus faktus. Dešimtadalis visu agentu - konspiraciniu bei susitikimų butų laikytojai. Visi likusieji - tai agentai stebėtojai, t. y. fiksuojantys priešišką veiklą. Jiems KGB sugaišdavo daugiausia laiko, bet nauda iš ju dažniausiai buvo trumpalaikè. Žr.: Денисов С., «Конкретизировать функции каждого агента», Сборник КГБ СССР 53, Москва, 1990, p. 68-69; Леган И., Андреев В., «Какой быть класификации негласных помощников», Сборник КГБ СССР 55, p. 64.

4 Šabajevaite L., Lietuvos socialine transformacija 1990-1997 metais, Vilnius: Vilniaus universiteto leidykla, 1999, p. 32.

${ }^{5}$ LR AT dokumentu rinkinys I, p. 346.

${ }^{6}$ Endriukaitis A., "Marijampolès sajūdyje veikè agentas "Astra Nr. 35348", Lietuvos aidas, 1992 m. sausio 8 d.; Endriukaitis A., „Operatyvinis kovinis būrys Šakiuose ir Vilkaviškyje”, ten pat, 1992 m. vasario 4 d.; Endriukaitis A., "Pakruojiečiai uoliai vykdè instrukcijas“, ten pat, 1992 m. rugpjūčio 12 d.; Endriukaitis A., "Jurbarko kagébistai tebedirba", Lietuvos aidas, 1992 m. spalio 8 d.; Endriukaitis A., "Agentas ypatingam periodui“, ten pat, 1991 m. lapkričio 9 d., Endriukaitis A., "Agento asmens byla", ten pat, 1991 m. lapkričio 23 d., Endriukaitis A., "Patikimi asmenys (apie verbavimo dokumentu pildymą)", ten pat, 1991m. lapkričio 29 d.; Endriukaitis A., "Prieš bažnyčią", ten pat, 1991 m. lapkričio 30 d.; Endriukaitis A., ",Voratinklis", ten pat, 1992 m. vasario 4, 14, 20, 29 d.; Endriukaitis A., "Voratinklis“, ten pat, 1992 m. kovo 19 d.; Varanauskas P., „KGB agentas planavo jèga nuversti Vytautą Landsbergi“", ten pat, 1992 m. rugsejo 26 d.; Varanauskas P., „Ketas' šnipinejja jėzuitą", ten pat, 1992 m. rugsèjo 22 d.; Varanauskas P., „Džanatas KGB sociologu apsuptyje", ten pat, 1992 m. rugpjūčio 26d.; Varanauskas P., "Dana - tarptautininkè", Ten pat, 1992 m. liepos 2 d.; Varanauskas P. , „Ket ir Antanaitis", ten pat, 1992 m. birželio 5 d.; Endriukaitis A., "Karalius", ten pat, 1992 m. balandžio 24 d. ir t. t.
} 
misijos KGB veiklai tirti nario Jurgio Jurgelio, ,', dèl neteisingų ir netikslių spaudos publikacijų keblioje padètyje atsiduria prokuratūra, tačiau komisija nè karto nepaneigė netiesos. Informacijos ir pavardžių skelbimas nebuvo reglamentuotas ịstatymu, neaptariamas komisijoje, nederinamas su Generaline prokuratūra. Taip buvo kompromituojami ir nekalti asmenys ${ }^{\prime 7}$. Keletas Aukščiausiosios Tarybos deputatų buvo apkaltinti bendradarbiavimu su KGB (Virgilijus Čepaitis, Kazimiera Prunskienė, Jokūbas Minkevičius, Vladimiras Beriozovas ir kt.). Teismas kai kuriuos iš ju pripažino buvusiais KGB slaptais bendradarbiais arba jie patys atsisakė Aukščiausiosios Tarybos deputatų mandatų. Iki naujų rinkimų Aukščiausiosios Tarybos deputato mandatas buvo atimtas tik V. Čepaičiui. $1992 \mathrm{~m}$. liepos 9 d. priimtame Seimo rinkimu isstatyme 97 str. buvo numatytas ipareigojimas kandidatams į Seimo narius viešai paskelbti apie sąmoningą bendradarbiavimą su kitų valstybių specialiosiomis tarnybomis ${ }^{8}$. KGB palikimo problema susieta tik su buvusiais slaptais bendradarbiais. Buvusiu KGB kadriniu karininku galimybès įsidarbinti nacionaliniam saugumui svarbiose institucijose nebuvo suvaržytos. Bet santykiuose su sovietine praeitimi įsivyraujant amnezijos (atseit „nereikia žvalgytis i praeitį“ ir pan.) ir reliatyvizavimo (tariamai, „visi kolaboravo “ ir pan.) strategijoms, 1993-1997 m. nebuvo žengta kitų teisinių žingsniu, ilgai nebuvo sukurta ar negalëjo veikti institucija, kuri tvarkytu, saugotų ir tirtų KGB palikimą. Baimindamiesi dèl KGB archyvų saugumo ir siekdami neleisti jų perkèlimo, buvę politiniai kaliniai ir tremtiniai 1993-1996 m. budèjo KGB rūmuose.

1996 m. Seimo rinkimus laimëjus dešiniosioms politinėms jẻgoms, vèl buvo sugrižta prie KGB bendradarbių liustravimo problemos sprendimo. 19981999 m. buvo sukurta tam tikra KGB agentų ir kadrinių darbuotojų liustracijos sistema. Galima ginčytis dèl jos efektyvumo ir pasekmių (neigiamų ar teigiamų) Lietuvai. Buvęs Seimo Nacionalinio saugumo komiteto pirmininkas Algirdas Katkus teigè, kad pirminis liustracijos įstatymo variantas buvo daug griežtesnis ir radikalesnis, tačiau jis sulaukè didelio pasipriešinimo bei daug pasiūlymu taisyti: „Iš esmės buvo priimtas toks ịstatymas, koks tuo metu galëjo „pereiti“ ${ }^{\prime 9}$. Negausus KGB rezervo karininkų būrys liko nuošalyje užprogramuojant ateityje sugrị̌imą prie neišspręstų KGB palikimo vertinimo problemų. 1999 m. liustracija palietė apie 300 KGB kadrinių darbuotojų (dirbusių strateginėse įmonėse, svarbiose valstybès įstaigose, švietimo sistemoje). 1999 m. prièmus Lietuvos Respublikos asmenu, slapta bendradarbiavusiu su buvusios SSSR specialiosiomis tarnybomis, registracijos, prisipažinimo, įskaitos ir prisipažinusiujų apsaugos įstatymą ir apibrěžus slapta bendradarbiavusių su buvusios SSSR specialiosiomis tarnybomis kategorijas, nustačius jų prisipažinimo tvarką bei įtvirtinus apribojimus asmenims, slapta bendradarbiavusiems su buvusios SSSR specialiosiomis tarnybomis, kurie įstatymo nustatyta tvarka neprisipažino su jomis bendradarbiavę, atėjo prisipažinti buvę KGB agentai. Buvęs VSD vadovas Mečys Laurinkus tikino, jog „,Liustracijos įstatymas išsprendè labai daug problemu,

\footnotetext{
7 Šabajevaitė L., (note 4) p. 34.

${ }^{8}$ Ten pat, p. 36.

${ }^{9}$ Kuzmickaitė J., „Prisipažinusiems - sankcijos, nutylëjusiems - atviri keliai“, Atgimimas 2, 2005.
} 
jam įsigaliojus prie bendradarbiavimą su KGB prisipažino apie 1500 žmonių, išreiškusiu pasitikẻjimą Lietuvos valstybe ${ }^{\prime 10}$.

\subsection{KGB rezervas}

Kam ir kaip KGB Lietuvos teritorijoje kūrè karininkų rezervą? Kad būtu aiškesnis ideologinis KGB veiklos pagrindimas, pacituosiu tik mažą dalį 1989 m. patvirtintų KGB mobilizacinio darbo nuostatų: „,SSSR KGB, kuri gina sovietinę valstybę ir visuomenę nuo priešo specialiuju tarnybu, užsienio antisovietinių centrų ir priešiškų vidaus elementų ardomosios veiklos, vienas svarbiausių uždavinių - išankstinis pasirengimas spręsti nurodytas užduotis grèsmès periodo ir karo metu“. „Grèsmés periodas ir karo metas" trumpai buvo įvardijamas kaip „ypatingas periodas“. KGB turëjo būti pasiruošusi skubiems veiksmams ypatingo periodo metu ir taikos meto ekstremaliomis sąlygomis, kuomet galëjo prireikti iš anksto kruopščiai atrinktu, patikrintu, bent minimaliai parengtų ir svarbiausia - patikimų naujų darbuotojų papildomoms funkcijoms vykdyti.

İ KGB atsargą Sovietų Sajungos Ginkluotuju pajejgų karininkai buvo pervedami remiantis minètais KGB mobilizaciniais ir pasirengimo „ypatingam periodui“" planais. Atrenkant karo prievolininkus operatyviniam darbui KGB struktūrose, pirmumą turèjo partinių-politinių struktūru, turintys juridinį išsilavinimą, darbo patirtį pramonès ir transporto įmonèse, iš komunistų partijos ir komjaunimo organizacijos nariai bei atitinkantys tarnybai KGB keliamus reikalavimus. Filosofas Vytautas Radžvilas teigė manąs, kad asmenys, sovietmečiu pasirinkę tokį ar kitokį bendravimo su KGB būdą, jau buvo susitapatinę su Sovietu Sajunga. „Manau, kad visus tuos žmones vienija vienas bruožas: jie tikrai netikèjo, kad Lietuva gali išsikovoti nepriklausomybę, - teigè filosofas. - Buvimas rezerviniu karininku iš dalies buvo sąlyga, leidžianti kaupti politinị kapitalą, jie galëjo tikètis sparčiau kilti karjeros laiptais ${ }^{\prime 11}$. Žurnalistas Valdas Vasiliauskas pastebi:

„Tačiau net ir čia nomenklatūra buvo apsirūpinusi lengvatomis. Kylantis karjeros laiptais karo prievolininkas darydavo „karjerą" ir karinëje įskaitoje: jis paprastai buvo perkeliamas į politiniu vadovu kategoriją. Ypač patikimas ir lojalus santvarkai - $\mathrm{i}$ KGB rezervą. Tai reiškè tik dar vieną nomenklatūros privilegiją, o ne bendradarbiavimą, juo labiau slapta, su KGB" ${ }^{\prime \prime 2}$.

Iš tikrujų buvimą ,"KGB rezerve" galima iš dalies vertinti ir kaip dar vieną buvusios nomenklatūros privilegiją, ir kaip galimybę sparčiau patekti į nomenklatūrines pareigas. Karjerizmas buvo viena iš ryškesnių dalies rezervistų bruožų. Kita vertus, į KGB rezervą buvo įrašyta ir daug niekados nomenklatūrai nepriklausiusių žmonių. Bet jų lojalumas komunistinei sistemai ir tinkamumas KGB veiklai buvo neabejotinai patikrinamas. Atrinktieji į KGB rezervą turëjo

${ }^{10}$ ELTA, M. Laurinkus: negalima 100 proc. pasitikèti sovietu specialiuju tarnybu medžiaga, $2005 \mathrm{~m}$. vasario mèn. $19 \mathrm{~d}$.

${ }^{11}$ Makaraitytè I., "Vertinimas - moralinis“, Atgimimas 4, 2005.

${ }_{12}$ Vasiliauskas V., "Revanšas: planas KGB rezervas“, Lietuvos rytas, 2005 m. sausio 17 d. 
pačias įvairiausias civilines specialybes: mokytojai, inžinieriai, teisininkai, įmonių ar ịstaigų vadovai, Komunistų partijos organizacinių struktūrų darbuotojai ir t. t. Tai nepatvirtina ",rezervistu“ skandalo metu išsakytu spèlioniu, kad ,,jame dominuoja sovietinès visuomenès elitas ${ }^{\prime 13} .2005 \mathrm{~m}$. vasario pradžioje TV3 televizijai paviešinus aukštu pareigūnų pavardes, kurie savo laiku buvo įrašyti ị KGB rezervą̨ ${ }^{14}$, tame sąraše buvo vos 70 pavardžių.

Sutikimas būti KGB rezerve buvo duodamas žodžiu. Pagal SSSR KGB mobilizacinio darbo nuostatus:

„SSSR Ginkluotuju pajėgu karo prievolininku atranka KGB organams sukomplektuoti pagal karo meto etatus vykdoma atliekant pirminę atranką pagal KGB-VRM įskaitas. Kandidatai, skirti karininkų pareigoms, kviečiami į karinius komisariatus siekiant gauti anketinius duomenis visiškam specialiam patikrinimui ir gauti jų sutikimą karo metu tarnauti KGB organuose [...], visoms kitoms pareigoms - be kvietimo. Karo prievolininkų atranką vykdo KGB organu mobilizaciniai darbuotojai, kadrinių aparatų darbuotojai, operatyviniai darbuotojai. [...] Pasibaigus specialiam patikrinimui ir nustačius jų tinkamumą dirbti KGB, atrinktieji kviečiami į karinius komisariatus pokalbiams, kurių metu išsiaiškinamas ju sutikimas tarnauti KGB karo metu. Karo prievolininkai davę sutikimą užpildo nustatyto pavyzdžio anketas" ${ }^{\prime 15}$.

Buvo vykdomas visapusiškas atrinktų karininkų specialusis patikrinimas. KGB teritoriniu padalinių ir KGB ypatingų skyrių darbuotojai surinkdavo charakteristikas apie kandidatus į KGB atsargą bei visada susitikdavo (prireikus - ir ne vieną kartą), aiškindavosi asmenines savybes pokalbio metu. Kariniai komisariatai buvo ịpareigoti netrukdyti KGB atstovams vykdyti atsargos kariškiu atrankos KGB tikslams.

KGB atsargos karininku asmens bylu sudarymas ir tvarkymas buvo vykdomas remiantis KGB prie SSSR Ministrų Tarybos 1978 m. birželio 20 d. įsakymo Nr. 0330 priedu ,Instrukcija apie kandidatų tikrajai karinei tarnybai ir darbui SSSR Ministru Tarybos valstybės saugumo komitete atranką ir patikrinimą “16 . To paties ịstatymo nuostatos buvo taikomos ir atrenkant etatinius kandidatus darbui (kadrinius darbuotojus) ir formuojant KGB atsargos karininku kontingentą. Pagal SSSR KGB 1978 m. birželio 20 d. atrankos ir patikrinimo instrukcijos 7-ą skyrių:

„Operatyvinių padalinių darbuotojai, kuriems tai pavesta, asmeniškai ištiria kandidatus, naudoja šiuo tikslu operatyvines pajėgas ir priemones, taip pat tokią jų ištyrimo formą, kaip patikrinimas operatyvinio pobūdžio pavedi-

13 Ten pat.

${ }^{14}$ Barkauskaitè O., „Tirs, kas nutekino informacija apie KGB rezervistus“, www.delfi.lt, 1702 2005 .

15 SSSR mobilizacinio darbo nuostatai (1989 m. projektas), Lietuvos Ypatingasis archyvas (toliau -LYA), f. K-1, ap. 46, b. 2833, 1. 217, 261. Davusių sutikimą būti įtrauktiems į KGB rezervą užpildytos anketos saugomos ju asmeninèse bylose dabartiniame Lietuvos Ypatingame archyve.

${ }^{16}$ Instrukcija apie kandidatu tikrajai karinei tarnybai ir darbui SSSR Ministru Tarybos valstybès saugumo komitete atranką ir patikrinimą, Totalitarizmo pasekmiu dokumentavimo centro archyvas (Latvija) (Centre for the Documentation Of The Consequences of Totalitarianism (Republic of Latvia). 
mais [...], siekiant nustatyti kandidato tinkamumą agentūriniam-operatyviniam darbui KGB centriniame aparate, KGB organuose jie (išskyrus asmenis, tiesiogiai pervedamus iš partinio, tarybinio ar komjaunuolių darbo) atitinkamo padalinio darbuotojo pasitelkiami (jei tam yra būtinos sąlygos) konkretiems operatyvinio pobūdžio pavedimams vykdyti ${ }^{17}$. Gaunant apie kandidatus informaciją apie ju netinkamumą tarnybai ar darbui KGB organuose ir kariuomenëje, KGB atsisakydavo nuo tolimesnio darbo su jais ${ }^{\prime 18}$

Pagal 1988 m. Lietuvos SSR KGB mobilizacinio pasirengimo pranešimą, siekiant sukomplektuoti KGB pagal karo meto („ypatingos padèties,,) etatus mobilizacinis poreikis buvo 903 žm., iš kurių 624 karininku ir 279 eilinių bei seržantu. Karininkai buvo skirstomi į KGB atsargos karininkus, kurių buvo 72, ir Ginkluotuju pajėgu atsargos karininkus, kurių buvo $552^{19}$. Tiek naujų darbuotojų reikëjo pakeisti kitur pervedamus KGB kadrinius darbuotojus, eiti etatiniu KGB karininku pareigas vykdant papildomas funkcijas: vadovaujant operatyviniams-koviniams būriams kiekviename rajone, vykdant prevencinius ,"nepatikimų asmenu" suemimo planus ir pan. KGB atsargos karininkų veiksmai priklausė nuo teritorinių KGB struktūrų gaunamų kovinio pasirengimo laipsnių. Pavyzdžiui, gavus signalą teritorinès KGB struktūros, papildytos atsargos karininkais, turëjo vykdyti ,ypatingas operatyvines priemones" sulaikant asmenis, kurie karo meto sąlygomis keltu ypatingą pavojų valstybei. $1989 \mathrm{~m}$. rugsëjo $29 \mathrm{~d}$. LSSR KGB pirmininkas Eduardas Eismuntas pasiūlè į sulaikomų asmenų sąrašą įrašyti ir , antisocialistinių neformalių organizacijų lyderius bei aktyvistus, kurie pasisako už egzistuojančios valstybinès santvarkos pakeitimą, gali organizuoti ar igyvendinti ekstremistines akcijas, tarp ju prievartinio, grupinio pobūdžio “20. Bet dèl numatytų skirtingų funkcijų ne visi Ginkluotuju pajègų atsargos karininkai buvo pervedami į KGB atsargos karininkų kategoriją. Visi KGB atsargos karininkai turejo tapti KGB operatyviniais darbuotojais. Be to, dalį numatyta skirti SSSR KGB Ypatinguju skyrių Pabaltijo karinei apygardai kariniu daliniu ypatinguju skyrių operatyviniais darbuotojais (1985 m. buvo numatyta tam skirti 185 KGB atsargos karininkus ${ }^{21}$, kurie turëjo sekti mobilizuojamuosius, aiškintis jų nuotaikas ir sekti politiškai nepatikimus žmones. I tokius poreikius ir buvo orientuojamasi sudarant KGB atsargos karininkų rezervą. $1989 \mathrm{~m}$. sausio $1 \mathrm{~d}$. KGB atsargoje buvo 357 karininkai, iš kurių 232 buvo pervesti iš Ginkluotuju pajègų atsargos (kiti - buvę kadriniai KGB darbuotojai) ${ }^{22} .1990$ m. gruodžio 27 d.

\footnotetext{
${ }^{17}$ Instrukcija, (note 16) 7 skyrius. KGB atsargos karininkų asmens bylose yra užuominų apie operatyvinių pavedimu davimą ir vykdymą. Žr.: LYA, f. K-1, ap. 52, b. 187; b. 82, 1. 19-22; b. 176, 1. 21-22; ap. 46, b. 2789, 1. 35-1, 35-2. Latvijos, Estijos ir Lietuvos teritorijose veikę Sovietu Sajungos padaliniai vadovavosi vienodomis instrukcijomis ir istatymais, bet KGB archyvai šiose šalyse išliko nevienodos struktūros. Latvijoje išliko daugiausia KGB veiklą reglamentavusiu isakymu ir instrukciju, Lietuvoje liko daugiau operatyvinès veiklos dokumentu, asmens bylu.

${ }^{18}$ Instrukcija, (note 17) 11 skyrius.

${ }^{19}$ Lietuvos SSR KGB mobilizacinio pasirengimo pranešimas (1988 12 30), LYA, f. K-1, ap. 46, b. 2833, 1. 6 .

${ }^{20}$ Ten pat, b. $2833,1.261$.

${ }^{21} 19850704$ išrašas Nr. M/0531, ten pat, b. 2711, 1. 31-4.

${ }^{22}$ Lietuvos SSR KGB mobilizacinio pasirengimo pranešimas, Ten pat, b. 2833, 1.7.
} 
Lietuvoje įskaitoje buvo 420 SSSR KGB atsargos karininku (iš jų 273 pervesti iš Ginkluotuju pajègu atsargos), o $1991 \mathrm{~m}$. kovo $25 \mathrm{~d}$. - 370 KGB atsargos karinin$\mathrm{ku}^{23}$. Net ir 1990-1991 m. daliai rezervistu, pervestų i KGB atsargą, atsisakant likti KGB „,rezerve“ (neskaičiuojant buvusių kadrinių KGB karininkų) skaičius siekè daugiau kaip 200.

$1989 \mathrm{~m}$. besikeičiant politinei situacijai Lietuvoje, KGB dokumentuose pažymima apie pirmuosius atsisakymus likti KGB rezerve ${ }^{24}$. Kodėl gi KGB rezervas nenunyko atkūrus Lietuvos nepriklausomybę? Vilniaus universiteto Filosofijos fakulteto profesoriaus Albinas Bagdonas kalba apie identifikavimąsi su valstybingumo idejja:

„Paskutiniu režimo [sovietinio - A.A.] dešimtmečiu prisitaikẻliškumas ir bendradarbiavimas su režimu retai buvo motyvuojamas ideologiniu pagrindu. [...] Ta dešimtmečiu priespauda išugdė amerikiečių psichologų aprašytą „išmokto bejėgiškumo,, elgseną. [...] Tokią elgseną paprastai lydi sąmonès susidvejinimas [...] Valdžios dviveidiškumas taip pat buvo aiškiai matomas. Ideologinė pompastika mažai ką bendra teturëjo su kasdiene praktika“25.

Kalbėdami apie dalį žmoniu, kurie yra dabartinejje Lietuvos valdžioje ir buvo įtraukti į KGB rezervą prieš 16-25 metus, galime įžvelgti ir tam tikrą psichologinę motyvaciją, nulemtą ,"išmokto bejejgiškumo" (atseit ",ką galejjau padaryti“", ,buvau tik vienas iš daugelio", ,,ir kiti taip elgèsi“ ar dar kaip nors kitaip motyvuojant savo pasirinkimą). 1990 m. kai kurie įtraukti į KGB atsargą karininkai dèl politinių motyvų atsisakydavo priimti KGB atsargos karininkų karinius bilietus, po to jie buvo išbraukiami iš ",KGB rezervo ypatingam periodui“. Po tokių atsisakymu LSSR KGB pirmininkas gen. mjr. Romualdas Marcinkus 1990 m. rugsëjo 28 d. įsakẻ visiems miestų ir rajonų KGB skyrių viršininkams, „,siekiant KGB atsargos karininkų ir KGB struktūroms skirtų Ginkluotujų pajègų karo prievolininkų patikimumo", atlikti papildomą šio kontingento (t. y. priklausiusių komandoms Nr. 300/1400 ir 300/1400B) patikrinimą. Pavyzdžiui, Klaipėdoje iš 30 apklaustų karininkų 8 atsisakẻ likti KGB rezerve, iš 30 seržantu ir eiliniu -8 taip pat atsisaké2 ${ }^{26}$. Kaune buvo apklausti 34 asmenys ir dèl politinių priežasčių atsisakè 5 KGB atsargos karininkai ${ }^{27}$ ir t. t. Kai kada su atsargos karininku buvo kalbama individualiai ${ }^{28}$ arba sprendžiama pagal jų veiklą, užimamas pareigas (priklausymą Sajūdžiui, išèimą iš LKP sudèties, darbą Lietuvos Respublikos valdžios struktūrose ${ }^{29}$ ). Ignalinos, Anykščiu, Varènos, Kupiš-

${ }^{23}$ Ataskaita apie darbą 1990 m. (1990 12 27), ten pat, b. 2767, 1.10-11.

${ }^{24}$ Telšių raj. KGB skyriaus viršininko pranešimas LSSR KGB Mobilizacinio skyriaus viršininkui, ten pat, ap. 45 , b. $2845,1.74$ atv.

${ }^{25}$ Prisitaikèliai, Atgimimas 3, 2005.

${ }^{26}$ Klaipėdos m. ir Lietuvos jūru baseino KGB skyriaus viršininko 19901204 pažyma, LYA, f. K-1, ap. 46 , b. 2727, 1. 84-86.

${ }^{27}$ Kauno m. KGB skyriaus viršininko 199011 raštas LSSR KGB Mobilizacinio skyriaus viršininkui, ten pat, 1. 88.

${ }^{28}$ Varènos raj. KGB skyriaus viršininko 19901112 pažyma, ten pat, 1. 63 atv.; Kauno m. KGB skyriaus viršininko 199011 raštas LSSR KGB Mobilizacinio skyriaus viršininkui, ten pat, 1. 88.

29 Śilalès raj. KGB skyriaus viršininko 19901105 pažyma, ten pat, 1. 80-80 atv.; Klaipèdos m. ir Lietuvos jūrų baseino KGB skyriaus viršininko 19901204 pažyma, ten pat, 1. 83 atv. 86. 
kio, Pasvalio, Prienu, Šalčininku, Švenčioniu, Širvintų ir kai kurie kiti KGB skyriai nepatikimu nerado. $1991 \mathrm{~m}$. kovo $25 \mathrm{~d}$. atskaitoje minimi 38 atsisakę likti KGB atsargoje 1990 m., o $1991 \mathrm{~m}$. sausio - kovo mèn. atsisakè likti atsargoje dar 1 bei 43 buvo išbraukti dèl motyvu, kurie trukdej juos panaudoti tarnyboje ${ }^{30}$. Bet tuo metu tarp atrankos kriterijų nebeliko priklausymo komunistinèms organizacijoms bei "ypatingo periodo metu" numatyta panaudoti sąveikoje su kariniais daliniais susiklosčius ,,ypatingoms situacijoms“31 166 KGB atsargos karininkus operatyvinių darbuotojų pareigose ${ }^{32}$ (neskaičiuojant kelių dešimčių numatytų darbui teritoriniuose KGB skyriuose). 1990 m. atsargos karininkų bylos pradètos siųsti už Lietuvos ribu, pirmiausia išsiunčiamos tų atsargos karininku asmens bylos, kurie jau buvo sulaukę 50 metų ir buvo išbraukti iš atsargos. Taigi $1990 \mathrm{~m}$. sausio 10 d. į Omsko KGB archyvą išsiųstos 33 asmens bylos. $1990 \mathrm{~m}$. vasario $21 \mathrm{~d}$. „dèl sudètingos operatyvinès padèties Lietuvoje“ i išsiųsta 141 KGB atsargos karininko byla. Tarp jų buvo pirmiausia pervestų i atsargą buvusių KGB kadrinių karininkų bylos, daugiausia majorų ir turinčiu aukštesnius karinius laipsnius. Kitos bylos liko ir dabar Lietuvoje yra saugomos Lietuvos ypatingajame archyve (fondas Nr. K-1, apyrašas Nr. 52).

Tuo tarpu buvęs VSD direktorius M. Laurinkus „rezervistų" skandalo metu teigè, kad , jokiomis sovietmečio laikotarpio bylomis nereikia pasikliauti 100 procentu“. Pasak M. Laurinkaus, KGB rezervo tema jau buvo diskutuojama rengiant Liustracijos įstatymą. VSD jau tuo metu buvo pateikusi įstatymą rengusiai darbo grupei informaciją apie KGB rezervo statusą ir vaidmeni sovietmečiu. „,KGB rezervo struktūra, mano giliu ịsitikinimu, buvo grynai popierinè biurokratinè struktūra, ir nemanau, kad pati susivokè, koks yra jos vaidmuo, ypač dar būsimo karo metu", - aiškino buvęs VSD vadovas. Galima sutikti, kad KGB rezervas buvo daugiau formali struktūra, bet atranka i ją, patikimumo patikrinimas, sutikimo bendrauti su KGB išgavimas pakartojo etatinio KGB darbuotojo atrankos ir patikimumo patikrinimo procedūras. Nors priklausymas KGB rezervui visuomenëje galëjo būti vertinamas neigiamai, kaip asmens garbę žeminanti aplinkybè, ,,rezervo“ tyrimas toliau nei ,,informacijos pateikimas" nepajudejjo. Prabėgus penkeriems metams po ,informacijos pateikimo“ iš žiniasklaidoje (savaitraštyje „Atgimimas“, dienraštyje „Lietuvos žinios“) paskelbtų duomenų visuomenè sužinojo, kad Seimo narys Alfredas Pekeliūnas 1985 m. buvo įrašytas į teritorinio KGB padalinio - Panevėžio m. KGB skyriaus mobilizacinius dokumentus ir numatytas operatyviniam darbui KGB teritoriniame padalinyje; Arvydas Pocius 1989 m. gruodžio mėn. buvo įrašytas į KGB Ypatingojo skyriaus Pabaltijo karinei apygardai sąrašus ir numatytas karinio dalinio, dislokuoto Vilniuje, Ypatingojo skyriaus operatyviniu darbuotoju; Antanas Valionis $1981 \mathrm{~m}$. buvo įrašytas į KGB Ypatingojo skyriaus Pabaltijo karinei apygar-

\footnotetext{
${ }^{30}$ Ataskaita apie darbą 1990 metais (1990 12 27), ten pat, b. 2767, 1.10.

${ }^{31}$ KGB pirmininkas E. Eismuntas 1989 m. gruodžio 8 d. prašè SSSR KGB Mobilizacinio skyriaus viršininko gen. mjr. A. B.Suplatovo susitarti su Lietuvoje dislokuotais kariniais daliniais, kad jie pridengtu pagrindinius KGB padalinius „ypatingu situaciju“ metu: Vilniaus ir Kauno KGB skyrius turëjo pridengti 7-oji gvardijos oro-desanto divizija, Klaipédos KGB 23-as pasienio būrys, Panevéžio KGB-18-os karinès-transporto gvardijos divizijos daliniai.

${ }^{32}$ LYA, f. K-1, ap. 46, b. 2727, 1. 57.
} 
dai sąrašus ir numatytas karinio dalinio, dislokuoto Sovietske (Kaliningrado sritis), Ypatingojo skyriaus operatyviniu darbuotoju. Viešumo trūkumas į atsakingas pareigas už nacionalinị saugumą atsakingose institucijose skiriant asmenis su neatskleistais ir viešai neįvertintais ne itin reprezentatyviais biografiniais faktais KGB rezervo problemos sprendimą pavertė skandalu.

\section{KGB „rezervo“ problema 2004-2005 m.}

\subsection{Skandalo genezè}

$2004 \mathrm{~m}$. keleto aukštų užsienio valstybiu pareigūnų politinę karjerą sužlugdè tiesioginės ar netiesioginès sąsajos su sovietų saugumu. Pavyzdžiui, Lenkijos Seimas atleido Jozefą Oleksy iš parlamento Žemujų rūmų pirmininko pareigú. Teismas nustatè, kad J. Oleksy bendradarbiavo su komunistinès Lenkijos slaptosiomis tarnybomis, bet nuslèpe šį faktą. Lietuvoje panaši problema dèl aukštu valdžios pareigūnų subrendo 2004 m. lapkričio mèn. (antrą kartą po 1991-1992 m.).

Seimo Pirmininkui Artūrui Paulauskui opozicinès Tèvynės sajungos atstovų buvo pateikta medžiaga, kurioje teigiama, jog $1990 \mathrm{~m}$. rugsẻji A. Pekeliūnas buvo įtrauktas į KGB komandos 300/1400 B, kurią sudare atsargos karininkai ir kareiviai, sąrašus. Seimo Pirmininkas A. Paulauskas kreipėsi į Valstybės saugumo departamentą, prašydamas patikrinti, ar jo pavaduotojas A. Pekeliūnas nenuslëpè savo ryšių su Sovietų Sajungos valstybės saugumo komitetu $\mathrm{KGB}^{33}$. Pekeliūnas tvirtino niekada su KGB nebendradarbiavęs, o apie jo įtraukimą į rezervo sąrašą girdįs pirmą kartą . „,Tai yra dešiniujų politikų darbas. Jie, matyt, turi archyvus ir surado popieriuką, kuriame yra mano pavarde $\dot{e}^{\prime / 35},-$ sake Pekeliūnas. Bet ",dešiniujų rankos" eskalavimas nepasiteisino besiplečiant „rezervistų "skandalui ir įtraukiant į jį vis naujus veikëjus. Reikëjo numatyti naujas santykio su praeities palikimu ir atmintimi strategijas.

Tuo metu, kai dar tik formavosi tolimesnių veiksmų strategijos ir buvo mėginama arba eiti oficialiais instituciniais keliais (prašant VSD patikrinti gautą informaciją), arba numatant taikyti tebegaliojusius ir „sąmoningai bendradarbiavusių su KGB“ galimybes apibrèžiančius įstatymus. Vyriausiosios rinkimų komisijos pirmininkas Zenonas Vaigauskas teigè, kad, jeigu paaiškètu, jog A. Pekeliūnas iš tiesų nuslèpé savo bendradarbiavimą su sovietiniu KGB, jam grèstų Seimo nario mandato atėmimas per apkaltą ${ }^{36}$. Anot komentatoriu, , ,greičiausiai dèl to, kad politikai užsibrèžè tikslą apginti žmones nuo 'KGB šmėklų' ir skatinti 'gyventi ne praeitimi, o šia diena', o galbūt ir dèl kitu priežasčiu, tai, kad tarp KGB rezervo karininku yra ir daug svarbesnes pareigas einančių asmenu, buvo nutylėta ${ }^{\prime 37}$. Valstybės saugumo departamentas (VSD) į A. Paulausko

${ }_{33}^{3}$ BNS, A.Paulauskas kreipesi i VSD dèl A. Pekeliūno ryšiu su KGB, 2004 m. lapkričio mèn. $30 \mathrm{~d}$.

${ }^{34}$ Ten pat.

${ }^{35}$ Ten pat.

${ }^{36}$ Ten pat.

${ }^{37}$ Makaraitytė I., „KGB rezervistų širmą praskleidus“, Atgimimas 1. 
užklausimą atsakė, kad „VSD apie A. Pekeliūno bendradarbiavimą su KGB duomenų neturi“. Tuomet buvusio Tẻvynès sajungos lyderio, Europos Parlamento nario Vytauto Landsbergio pareiškimu, kad ,toks tokį dengia“38, buvo išprovokuotas tolimesnis dèmesys šiai problemai.

Iš savaitraštyje "Atgimimas“ pasirodžiusios informacijos paaiškèjus, kad Valstybės saugumo departamento generalinis direktorius A. Pocius ir Užsienio reikalų ministras A. Valionis buvo įtraukti į KGB rezervo sąrašus, siūlymai taikyti ,,riebaus brūkšnio“ tarp praeities ir dabarties strategiją buvo patys populiariausi: „Užuot sukę galvą, kaip efektyviau panaudoti ES paramos milijardus, mes rausiamès senose KGB bylose ${ }^{\text {“39 }}$, - teigè įtakingo dienraščio „Lietuvos rytas" žurnalistas V. Vasiliauskas. Bet, anot žurnalistės Indrès Makaraitytės, pareigūnai i aukštas pareigas buvo paskiriami „sąmoningai nuslepiant ne itin reprezentatyvius biografijos faktus ${ }^{\prime 40}$.

\subsection{Veiksmų strategijų pasirinkimas}

Santykyje su praeities represijomis ir represinėmis struktūromis (KGB) visuomenių atmintyje ir elgsenoje dažniausiai susiklosto štai tokios strategijos: kolektyviné amnezija, kai keblesni momentai „pamirštami“ ir viešojoje atmintyje apie juos vengiama kalbèti (konkrečia forma tai pasireiškia ir kaip „,riebaus brūkšnio" tarp praeities ir dabarties pozicija); kaltès perkèlimas pavienèms žmoniu grupėms ir tụ grupių demonizavimas (pavyzdžiui, „,buržuazija“, ,"komunistai“, „,naciai“); atsakomybės ir kančių reliatyvizavimas (,visi kentëjo“, „,visi kolaborantai“ ir pan.); viktimizacija, kai nukentëjusi grupé ar visuomenė suvokiama kaip auka; diskusija ir nuolatinis atminties permąstymas, Jurgeno Habermaso įvardytas kaip „,atminties darbas ${ }^{\prime 41}$. Atminties permąstymo strategija (ją galima pavadinti ir viešumo bei liustracijos strategija) siekiant visuomenès sutarimo yra produktyviausia, jei ši diskusija vieša, atvira, sąžininga ir joje girdima visų visuomenės grupių patirtis bei atmintis. Iš dalies taip galima pavadinti ir 2004-2005 m. sandūroje vykusi „,rezervistų" problemos permąstymą, nors kyla klausimas, kiek tai buvo daroma sąžiningai ir atvirai. Amnezijos ir reliatyvizavimo strategijos, specialistų įvardijamos kaip ypač nekonstruktyvios, atidedančios žmonėms svarbiu problemų sprendimą bei „visuomenės sutartį“ ir drauge trukdančios susitelkti ties dabartimi ${ }^{42}$, pradejo reikštis kur kas rafinuotesnemis formomis negu anksčiau (pirmiausia įstatymais apribojant galimybę tirti, vertinti ir viešinti KGB dokumentus ne valstybinèms institucijoms arba tokią veiklą iš anksto vertinant kaip politinę kovą ar galimą politinės kovos irankị).

\footnotetext{
${ }^{38}$ Gorienė G., „A.Paulauskas Lietuvą užvaldys Rusijos masinio panaudojimo psichiniu ginklu“, Laisvasis laikraštis, 2005 sausis.

${ }^{39}$ Vasiliauskas V. , (note 12).

${ }^{40}$ Makaraitytė I. , (note 39).

${ }^{41}$ Šutinienè I., "Posovietinè dilema“, www.delfi.lt, 27012005.

${ }^{42}$ Ten pat.
} 
Atminties ir santykio su praeitimi permąstymo strategijos (įvardijamos kaip produktyviausios) šalininkai buvo kaltinami sukèlę visuotinę sumaišti, politinį chaosą, destruktyvias aistras, kurios sukiršintų visuomenę, sugriautu jos solidarumą ir tarpusavio pasitikèjimą. ,"Čia buvo pradètas kur kas aukštesnio lygio politinis žaidimas “43, - teigè dienraščio "Lietuvos rytas“ komentatoriai. İvertinus buvimą KGB rezerve tik kaip papildomą nomenklatūros privilegiją, o ne papildomą galimybę siekti karjeros tarp komunistinio režimo nomenklatūros „pasitikrinus“ lojalumą tuometinei sistemai, kilusio skandalo tikslas buvo vertinamas kaip kairiuju - dešiniuju priešpriešos bei vykusios politinės kovos rezultatas: „dešinieji ketino smogti ir kitiems partinių mokyklu absolventams ir visai nomenklatūrai, su Darbo partija sugrịžusiai į valdžiąa ${ }^{44}$, sugriauti valdančią koaliciją". KGB rezervistų skandale sutapo daugybẻ interesų: ,,dešiniuju - sustabdyti nomenklatūrą, paksininkų - atsirevanšuoti A.Paulauskui “45 . Iš kitos pusès, KGB rezervo duomenu paviešinimas buvo vertinamas ir kaip vidinès, plačiai publikai neregimos politinès kovos veiksmas siekiant bent kiek susilpninti Seimo Pirmininko politinę galią perimant iš jo Generalinę prokuratūrą ir Valstybès saugumo departamentą ${ }^{46}$.

Dar iki Liustracijos komisijai priimant sprendimą apie „,KGB rezervo karininkų “ bendradarbiavimo su KGB pobūdi, ministras A. Valionis „Atgimimui“ teigè nenorįs nieko komentuoti, nes iš atsakingų Lietuvos instituciju jis yra gavęs atsakymą, jog tokia veikla nèra traktuojama kaip ",slaptas“ bendradarbiavimas su KGB ${ }^{47}$. Slapta duotas sutikimas būti įtrauktam į KGB rezervą, dalyvauti KGB rengtuose rezervo apmokymuose neabejotinai rodè sutikimą bendradarbiauti susiklosčius atitinkamoms situacijoms. Bet, kaip minèta, VSD realiai rezervo atsiradimo genezės netyrè ir slaptos (ir asmeninės) informacijos apie KGB atsargos karininkus buvimo Rusijos specialiujų tarnybų archyvuose nesiejo su galimomis grèsmėmis nacionaliniam saugumui. Tuo tarpu VSD vadovas A. Pocius „Atgimimui“" teigè, kad apie įtraukimą į KGB karininkų rezervą jis nieko nežinojęs ir tik Lietuvos nepriklausomybès laikotarpiu supratęs, kad KGB buvo užvedusi bylą: „,Maždaug 1993-1994 m. sužinojau, kad yra kažkokie KGB dokumentai ir kad jie gali būti panaudoti prieš mane ${ }^{\text {"48 }}$. Patekusieji i tyrimo akirati savo situaciją vertino arba kaip sąmoningą, dar KGB parengtą provokaciją, arba kaip aukščiausių politikų rate aptartą, bet nereikšmingą problemą.

Tai, kad neigiamas visuomenės požiūris ị santykius su KGB darè įtaką ir URM ir VSD vadovybès darbui ir galëjo netiesiogiai sukelti grèsmę nacionaliniam saugumui, destabilizuoti politinę situaciją arba padėtį už nacionalinį saugumą atsakingose institucijose, paryškino ir žiniasklaidoje pasirodę komentarai apie situaciją VSD. Anot komentatoriu, A. Pocius nekontroliuoja padėties Saugumo departamente ir ne visi pavaldiniai lojalūs dabartiniam vadovui. Po

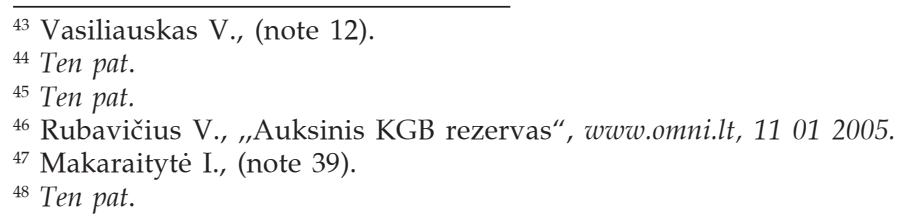


informacijos apie VSD generalinio direktoriaus A. Pociaus buvusius ryšius su KGB paskelbimo politikos savaitraštyje "Atgimimas“, Ypatingajame archyve saugomos bylos kopijos ",paslaptingu ir paslaugiu ranku“" buvo perduotos kitoms žiniasklaidos priemonèms. „Lietuvos žinios“" parengè keletą išsamiu publikacijų iš byloje esančios medžiagos. Bet VSD vidinè trintis yra tik viena iš jau anksčiau prasidejjusios kovos dèl įtakos VSD vadovybei pasekmių. Politinio proceso stebėtojai atkreipé dèmesi, kad įtampa dèl to, kas gali vadovauti Valstybės saugumo departamentui, kilo baigiantis buvusio VSD direktoriaus M. Laurinkaus kadencijai. Apogëju ji pasiekè tuometiniam, dabar jau nušalintam nuo pareigų Prezidentui Rolandui Paksui į VSD direktoriaus postą pasiūlius KAM II departamento vadovą Gintarą Bagdoną. $2004 \mathrm{~m}$. pavasarị, pasibaigus apkaltai, VSD generaliniu direktoriumi Laikinasis Prezidentas A. Paulauskas paskyrè M. Laurinkaus siūlytą buvusį jo pavaduotoją A. Pocių. ,„Atgimimui“ jau rengiant medžiagą apie A. Pociaus ir politikų sąsajas su KGB, kai kurie kalbinti asmenys būgštavo, esą tokios informacijos paskelbimas būsiąs naudingas kovojantiems dèl įtakos VSD. Ta konkurencija tarp VSD sienu, pasireiškianti informacijos nutekinimu, problemų slépimu ir jos viešinimu tada, kai naudinga kuriai nors dèl įtakos konkuruojančiai grupuotei, galèjo grèsti valstybės saugu$\mathrm{mui}^{49}$.

Plečiantis „rezervistų skandalui ir ịji įtraukiant už Lietuvos nacionalinį saugumą atsakingų institucijų vadovus, reikèjo numatyti naujas, efektyvesnes veiksmų strategijas. Kilęs KGB rezervo skandalas parodė „ypatingą mūsų valdančiojo elito kokybę, tam tikrus visuomenès būvio bruožus ir naujus nesibaigiančios politinės kovos veiksmus ${ }^{\prime \prime 50}$. Kitaip tariant, sąsajos su buvusia komunistine nomenklatūra ir tiesioginès ar netiesioginès sąsajos su jos interesus gynusiu KGB rodè ir dalies valdančiojo elito būseną ir galimybes jam daryti įtaką. Gana greitai pradejo formuotis politinių partijų lyderiu pozicijos „rezervistų“ atžvilgiu, kuriose buvo numatomi galimi tolimesni veiksmai. Buvo siūloma pareigūnams atsistatydinti, kreiptis ị liustracijos komisiją, paviešinti visų rezervistų pavardes, pradèti parlamentinį tyrimą.

\subsection{Atminties permąstymo - liustracijos ir viešumo strategija}

Laikantis viešumo strategijos, „,rezervistų statuso“ ivertinimas turëjo priklausyti asmenu, slapta bendradarbiavusių su buvusios SSSR specialiosiomis tarnybomis, veiklos vertinimo komisijai. İ šią tarpžinybinę komisiją buvo deleguojami atstovai iš VSD, Lietuvos gyventoju genocido ir rezistencijos tyrimo centro bei Generalinès prokuratūros. Komisijos pirmininkas (VSD atstovas) Vytautas Damulis dar KGB rezervininku skandalo pradžioje, kai Premjeras Algirdas Brazauskas paprašè Liustracijos komisijos įvertinti A. Valionio ir A. Po-

\footnotetext{
49 "Žvilgsnis", Atgimimas 4, 2005.

${ }^{50}$ Rubavičius V., (note 46).

${ }^{51}$ BNS, Liustracijos komisija lieka be vadovo, $2005 \mathrm{~m}$. vasario $8 \mathrm{~d}$.
} 
ciaus ryšius su KGB, yra minëjęs, kad Liustracijos komisija neturi teisinio pagrindo tirti KGB rezervininku veiklos. Anot jo, Liustracijos komisijai yra nustatyta tirti tik tuos, kurie bendradarbiavo su KGB, o pagal dabar galiojančius įstatymus buvimas rezerve nevertinamas kaip sąmoningas bendradarbiavimas su šia organizacija ${ }^{51}$. Bet Liustracijos komisijos įvertinimo pareikalavo ir opozicinè Liberalu ir centro sajunga. LCS pirmininko Artūro Zuoko manymu, žengę toki žingsnį ir sulaukę Liustracijos komisijos tyrimo išvadų, aukšti pareigūnai galètų toliau ramiai dirbti, išvengdami visuomenëje galinčių kilti įvairių interpretacijų dẻl jų patikimumo ${ }^{52}$.

Iš tikruju Lietuvoje galiojantys įstatymai nevienareikšmiškai apibrèžia priklausymą KGB rezervui. Pagal $2000 \mathrm{~m}$. įsigaliojusi ,,Asmenu, slapta bendradarbiavusiu su buvusios SSSR specialiosiomis tarnybomis, registracijos, prisipažinimo, įskaitos ir prisipažinusiujų apsaugos" ịstatymą, KGB rezervininkams, priešingai nei kadriniams sovietų saugumo darbuotojams, nereikejo kreiptis i specialią Liustracijos komisiją. Tačiau $1991 \mathrm{~m}$. pabaigoje ịsigaliojusiame įstatyme „Dèl deputatų, įtariamų sąmoningu bendradarbiavimu su kitų valstybiu specialiosiomis tarnybomis, mandatu patikrinimo" buvo nurodyta, kad „,bendradarbiavimo" sąvoka apima asmens įtraukimą į KGB (MGB) ar kitų specialiujų tarnybų sąrašus ar užverbavimą; kitokią sąmoningą ir sistemingą (du ir daugiau kartų) veiklą; žinių KGB ar kitoms specialiosioms tarnyboms teikimą, užduočių davimą ar vykdymą. Liustracijos komisijos narè Birutė Burauskaitė teigè, jog rezervo karininkų neįtraukimą į įstatymą galëjo nulemti ta aplinkybė, kad jų ryšys su KGB atrodẻ kitoks, turintis mažesnị lojalumo šiai tarnybai laips$\mathrm{ni}^{53}$. Vis delto nors Liustracijos komisija ketino apsispręsti, ar priklausymas KGB rezervui vertintinas kaip sąmoningas bendradarbiavimas su sovietų saugumu, bet vienareikšmiškai įvertinti sovietų saugumo rezervo statusą turimos medžiagos nepakako ${ }^{54}$. Atsirasti rezerve be įtraukiamo asmens žinios buvo neįmanoma, bet ",sąmoningo bendradarbiavimo" apibrěžimas šiuo atveju buvo esminis. Liustracijos komisija, pradejjusi šį klausimą spręsti, greitai darėsi neveiksni. Ivykiai paskatino diskusijas apie Liustracijos komisijos veiklos efektyvumą. Valstybès saugumo departamento (VSD) vadovas A. Pocius vienas pirmuju pareiškè savo įsitikinimą, kad iki šiol departamentui išlikusi pavaldi Liustracijos komisija ateityje turi tapti savarankiška struktūra, departamentas Liustracijos komisijai turètų tapti pagalbininku, komisijos sudètis turi būti atnaujinta ir naujuoju pirmininku turi tapti gerai visuomenei žinomas asmuo. „Komisija turètų būti visiškai savarankiška, priimti savarankiškus sprendimus, vertinant darbo grupès atliekamą darbą bei pateikiamą medžiagą ${ }^{455}$, - teigè A. Pocius. Iš tikruju VSD deleguoti komisijos nariai drauge buvo ir darbo grupès nariai ir negalëjo būti iki galo savarankiški ir nešališki. Liustracijos komisijai vadovavęs VSD Kontr-

52 „UR ministras ir valstybès saugumo šefas turi pereiti liustracijos rentgeną", Lietuvos rytas, $2005 \mathrm{~m}$. sausio $10 \mathrm{~d}$.

${ }^{53}$ Kuzmickaitè J., „Prisipažinusiems - sankcijos, nutylëjusiems - atviri keliai“, Atgimimas 2, 2005.

${ }^{54}$ ELTA, Liustracijos komisija įvertins KGB rezervo statusa, 2005 vasario mèn. $7 \mathrm{~d}$.

${ }^{55}$ ELTA, Aleknaite K., A.Pocius: Liustracijos komisija negali būti pavaldi VSD, 2005 m. vasario $21 \mathrm{~d}$. 
žvalgybos valdybos viršininkas V. Damulis iš komisijos pirmininko pareigu pasitraukè savo noru. Skatinti atsistatydinti ir kiti komisijos nariai.

Komisija, ir iki tol negalejusi pasigirti savo veiklos efektyvumu, nuo KGB rezervo problemos sprendimo dar spejo nusišalinti. Liustracijos komisija patvirtino savo išvadą, jog i KGB rezervą įtraukti asmenys nèra tapatintini su sovietinio saugumo slaptaisiais bendradarbiais. Liustracijos komisijos pirmininkas V. Damulis teigè, kad ši išvada nėra specialiai skirta kuriai nors institucijai ir buvo padaryta ,,ištyrus archyvuose saugomus su KGB susijusius dokumentus, apklausus KGB rezervistų bylas praeityje tvarkiusius asmenis ir archyvų tvarkytojus “56. Bet tai kilusios įtampos nesumažino.

Parlamentiné darbo grupé, rengusi pataisas su sovietinių specialiujų tarnybų veiklos vertinimu susijusiems įstatymams, pasiūlè pratęsti liustracijos terminą. „,Darbo grupè labiau linksta, jog reikètu pakartoti, pratęsti prisipažinimo terminą ${ }^{\prime 57}$, - teigè Nacionalinio saugumo ir gynybos komiteto (NGSK) pirmininkas Alvydas Sadeckas. Pradėta svarstyti, kaip pakelti Liustracijos komisijos lygmenį ir pakeisti formavimo principus, transformuojant ją iš žinybinès į žinybinę-visuomeninę. Anot A. Sadecko, buvo apsvarstytas variantas, jog į Liustracijos komisiją narius galètų deleguoti ir aukščiausieji valstybės asmenys - Prezidentas, Premjeras, Seimo Pirmininkas.

Su liustracijos procesu glaudžiai buvo susijusi KGB archyvų viešumo problema. KGB archyvų įslaptinimas buvo vertinamas kaip įnagis, kuriuo specialiosios tarnybos, valdančioji nomenklatūra valdẻ dalį visuomenès, versdami ją savuju kovu dèl valdžios ir politinès įtakos įkaite ${ }^{58}$. Skirtingų interesų ir tikslų vedami liberalcentristai, konservatoriai, Darbo partija pasisakė už KGB archyvų viešinimą.

„Visuomenei turètų būti paviešinti visu KGB rezervo karininkų sąrašai ${ }^{59}$, vengiant užsienio valstybiu specialiuju tarnybų šantažo", - teigė A. Zuokas ${ }^{60}$. Tam siūlyta tobulinti teisės aktus, pirmiausiai prieštaringai vertinamą naudojimąsi archyvais reglamentavusị ịstatymą, keliems dešimtmečiams apribojantị priējimą prie sovietų specialiujų tarnybų archyvu ${ }^{61}$. Darbo partijos frakcija prisijungè prie raginimų paviešinti Ypatingojo archyvo medžiagą ir buvusių KGB bendradarbių sąrašus ${ }^{62}$. Darbo partijos frakcijos nuomone, Ypatingasis archyvas turètų būti visiškai atviras. Vienas socialdemokratų lyderių Juozas Olekas teigè esąs už tai, kad visi sovietų saugumo rezervininkai būtų paviešinti, ,,kad niekas nebešniukštinètu“ “' ${ }^{\prime \prime 3}$ Kartu, anot jo, būtu užkirstas kelias asmenims, turëjusiems galimybę pavartyti KGB bylas, retkarčiais išmesti i viešumą informaciją apie vieną ar kitą aukštą pareigūną arba visuomenès veikèją. Panašiai svarstė ir skandalo epicentre atsidūręs VSD generalinis direktorius A. Pocius, klausimą dèl

${ }_{56}$ BNS, KGB rezervistai - ne slaptieji KGB bendradarbiai, $2005 \mathrm{~m}$. vasario $21 \mathrm{~d}$.

57 BNS, Siūloma pratęsti liustracijos termina, $2005 \mathrm{~m}$. vasario $21 \mathrm{~d}$.

58 Rubavičius V., (note 46).

59 „UR ministras ir valstybès saugumo šefas turi pereiti liustracijos rentgena, teigia liberalcentristai“", Lietuvos rytas, $2005 \mathrm{~m}$. sausio $10 \mathrm{~d}$.

60 Ten pat.

${ }^{61}$ Ten pat.

62 "Darbiečiai ragina paviešinti KGB rezervo sąrašus", www.delfi.lt, 11012005.

63 ,JJ. Olekas: priẻmus radikalų sprendimą, A. Pociui būtų ramiau gyventi“, ten pat. 
KGB rezervistų sąrašų paviešinimo siūlydamas spręsti nedelsiant, kad būtų nutraukta „,raganų medžioklè". Užsienio reikalų ministras taip pat neprieštaravo archyvuose saugomos KGB bylos paviešinimui ${ }^{64}$. Liberalcentristu, socialdemokratu, socialliberalų ir Darbo partijos siūlymų bendrumas buvo tas, kad viešumo siekta norint apsaugoti žmones nuo šantažo ir baigti ,,spekuliaciją“ šia tema. Diskusija ir nuolatinis atminties permąstymas, t. y. , ,atminties darbas“", nebuvo siūlomas.

Vykstant vadinamojo KGB rezervo skandalui, Seimo Tèvynės sajungos frakcijos seniūnas Andrius Kubilius pasiūlè paviešinti Ypatingojo archyvo medžiagą ir paskelbti buvusių KGB bendradarbiu sąrašus - ,pasekti čekų ir slovakų pavyzdžiu ir Ypatingojo archyvo bylas perkelti į interneto puslapius“. Čekai 2003 m. savo VRM puslapyje paskelbė 75 tūkst. buvusių slaptujų tarnybų bendradarbiu pavardžiu, slovakai informaciją apie 21 tūkst. buvusių bendradarbių pavardžių pateikė internete ${ }^{65}$. A. Kubiliaus nuomone, Lietuvoje galiojanti tvarka ir bandymai archyvus įslaptinti dar $70 \mathrm{~m}$. jokių problemu, su kuriomis susiduriame šiandien, neišsprendžia, o tik dar labiau jas gilina: „Vèl susidursime su ta pačia problema, kai paaiškès nauji faktai apie kokių nors valdžios žmonių bendradarbiavimąa"66.

Viešumas šioje srityje į Lietuvą buvo „importuotas“ iš Lenkijos. Dešiniuju jègu pažiūras reiškianti interneto svetainè ",ABCnet.com.pl“ Lenkijoje 2005 m. sausio $13 \mathrm{~d}$. patalpino į lenkų kalbą išverstą dokumentą $-1989 \mathrm{~m}$. gruodžio $26 \mathrm{~d}$. tuometinio Lietuvos SSR Valstybės saugumo komiteto pirmininko Eismunto pasirašytą įsakymą ir kelis ankstesnius jo potvarkius dèl sovietu armijos karininku įtraukimo į KGB rezervą. Minètame sąraše buvo 61 asmuo, tarp ju - ir Lietuvos Valstybės saugumo departamento generalinis direktorius A. Pocius ${ }^{67}$. Lietuvoje iki tol niekas neskelbė KGB rezervistų sąrašo, kadangi jis buvo konfidencialus. Seimo specialiajai komisijai, tiriančiai aukštų valstybẻs pareigūnų įtraukimo i KGB rezervą aplinkybes, vadovaujantis Skirmantas Pabedinskas ịspèjo, kad „,tai tik pakenks visuomenei, kadangi sąrašas yra netikslus, o vietomis netgi akivaizdžiai suklastotas ${ }^{\prime \prime 68}$. Sąrašą Lietuvos žiniasklaida paviešino. Tuomet pradèjo aiškèti, kad ị ,,rezervistü skandalo sūkurị gali būti įtraukti ne tik Naujosios sajungos, bet ir Darbo, Socialdemokratų ir kitu partijų nariai.

\subsection{Parlamentinis tyrimas ir teisès aktụ tobulinimas}

Sąmoningo ir „nesąmoningo “ bendradarbiavimo su KGB, buvimo KGB rezerve problemą pirmiausiai buvo siūloma spręsti tobulinant teisès aktus, pirmiausia nuo $2000 \mathrm{~m}$. galiojančio „,Asmenu, slapta bendradarbiavusių su buvusios SSSR specialiosiomis tarnybomis, registracijos, prisipažinimo, isskaitos ir prisipažinusiųjų apsaugos" įstatymą bei taip išspręsti KGB rezervo karininkų problemą ${ }^{69}$.

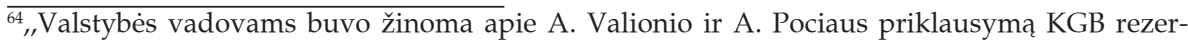
vui", www.delfi.lt, 07012005.

${ }^{65}$ BNS, Andrius Kubilius: Archyvai turètu būti atviri visuomenei, 2005 m. sausio $10 \mathrm{~d}$.

${ }^{66}$ Gorienè G., (note 38).

${ }^{67}$ ELTA, BNS, A.Anušauskas: KGB rezervistu sqarašas internete - tikras, $2005 \mathrm{~m}$. vasario $16 \mathrm{~d}$.

${ }^{68}$ Paaiškejjo paskelbto sąrašo tikrumas, bet jis nebuvo surastas Lietuvos Ypatingajame archyve.

${ }^{69}$ Olekas J., (note 63). 
Kiti siūlymai buvo susiję su teisės aktu, atveriančiu visus KGB archyvus, prièmimu, taip paskatinat laisvos pilietinės visuomenės kūrimąsi. Tai akcentavo opozicinè Tèvynès sajunga: ,,[...] inicijuoti tokias galiojančios tvarkos ir Archyvu įstatymo pataisas, kurios Ypatingajjį archyvą padarytų visiškai atvirą “70 .

I KGB „rezervo“" problemos svarstymą įsitraukiant vis naujoms politinėms jègoms, galiausiai vyraujančia strategija tapo parlamentinis tyrimas. Seimo Liberalu demokratu frakcijai numačius inicijuoti parlamentinès komisijos i̊steigimą, kuri ištirtų faktus apie aukštu pareigūnų sąsajas su KGB struktūromis $^{71}$, kitos politinės partijos kurį laiką skeptiškai vertino savo oponentų buvusiame Prezidento skandale pastangas.

Liberalcentristai skeptiškai vertino parlamentinès komisijos sudarymą, bet siūlè pakviesti A. Valionį ir A. Pocių atsakyti ị parlamentarų klausimus Seime. Tẻvynès sajungos frakcijos seniūnas A. Kubilius yra paraginęs minėtus pareigūnus patiems atsakyti į klausimą, ar jie gali toliau gerai atlikti savo dar$\mathrm{bac}^{72} .2005 \mathrm{~m}$. sausio mèn. viduryje paaiškèjo, kad valdančioji dauguma sudarys komisiją. Parlamentiniam tyrimui numatyta surinkti duomenis apie trijų valstybės pareigūnų sąsajas su sovietų saugumu - Užsienio reikalų ministro A. Valionio, Valstybės saugumo departamento generalinio direktoriaus A. Pociaus ir Seimo vicepirmininko A. Pekeliūno ${ }^{73}$. Anot liberaldemokratu, šis sprendimas ikurti komisiją, kurioje ",korektiškiau suformuluoti klausimai“ , reiškè, kad komisija nesiaiškins, ar pareigūnai, priklausę KGB rezervui, nemelavo, teigdami, kad to nežinojo; sykiu nebus nagrinëjamas ir klausimas apie moralinę pareigūnų teisę dirbti valstybės darbą, paaiškèjus jų ryšiams su užsienio slaptosiomis tarnybomis; nebus domimasi ir tuo, ar valstybės vadovai žinojo apie skiriamu pareigūnų priklausymą KGB rezervui ${ }^{74}$. Atrodo, tiek pozicija, tiek opozicija KGB rezervo nevertino kaip nacionaliniam saugumui aktualios problemos dèl įsivyravusio požiūrio užbrežti „,riebų brūkšnị“" tarp praeities ir dabarties bei vertinti kažkada į rezervą patekusių asmenų dabartinius nuopelnus.

\section{5. ,,Riebus brūkšnys“ ir kolektyvinès amnezijos požymiai}

XX a. istorinè patirtis rodo, kad visuomenè anksčiau ar vèliau grižta prie neišspręstų atminties problemų. Net viešojoje plotmëje aiškiai įvertinus nusikalstamą praeiti, išlieka daug praeities nutylëjimų privačiuose žmonių gyvenimuose ir savitarpio santykiuose. „Pamiršta“ arba paneigta žmogui svarbi asmeninè praeitis destruktyviai veikia tiek asmenybę, tiek, kaip masinis reiškinys, visuomenę. Bet į tai nebuvo atsižvelgta pritaikant amneziją bei reliatyvizmą santykiui su sovietine praeitimi. To rafinuota išraiška tapo aukščiausių šalies

\footnotetext{
70 BNS, (note 65).

${ }^{71}$,R. Paksas teigia, kad pareigūnų ryšiai su KGB buvo slepiami sąmoningai“, www.delfi.lt, 11 012005.

${ }^{72}$ Mazuronis V., „Kam ir kodèl reikia ,užmiršti“" praeitį?”, www.omni.lt, 10012005.

${ }^{73}$ ELTA, Liustracijos komisija ịvertins KGB rezervo statusq, $2005 \mathrm{~m}$. vasario $7 \mathrm{~d}$.

74 „,Valentinas Mazuronis: Alternatyvioji komisija aiškinsis alternatyvią tiesą", www.delfi.lt, 18012005.
} 
pareigūnų pasirinkta ,,žinojimo“ apie KGB rezervistus taktika (tariamai aktuali tik skiriant i pareigas).

Nepamatavus, kiek viešai neišspęstos praeities įvertinimo problemos destruktyviai gali paveikti visuomenę ir skandalu paliestas institucijas ir ar tai gali tapti nacionaliniam saugumui aktualia problema, imtasi vadinamosios „,riebaus brūkšnio" politikos: praeitis nuo šiandienos atskiriama ir vieninteliu valdininku vertinimo kriterijumi turëjo tapti kompetencija ir lojalumas naujai vyriausybei. Prieš patvirtinant A. Pocių VSD vadovu, jis $2004 \mathrm{~m}$. balandžio $27 \mathrm{~d}$. Seime buvo paklaustas, ar bendradarbiavo su KGB - ar kaip agentas, ar kaip „,doverennoje lico“ (rus. patikimas asmuo), ar kaip kitaip. A. Pocius atsakè: „Tikrai ne. Nesu susijęs su minèta struktūra ${ }^{75}$. Dar 1992-1993 m. buvau girdëjęs gandu, kad egzistuoja tam tikri su manimi susiję dokumentai, bet ị tai nereagavau. [...] Vèliau prašiau vadovybės ištirti aplinkybes, bet jie užtikrino, kad tai nèra problema "“76.

Seimo Pirmininkas A. Paulauskas pareiškè, kad tiek ministro, tiek Valstybès saugumo departamento (VSD) generalinio direktoriaus praeities faktai šiuo metu viešinami turint tam tikrų tikslu, taip pat ir politiniu, - siekiant mesti šešèli šiems pareigūnams, suabejoti jų lojalumu ir didinti įtampą valdančiojoje koalicijoje. Anot Seimo Pirmininko, dabartinio VSD generalinio direktoriaus biografija taip pat ,"nebuvo paslaptis nei skiriantiems, nei rekomenduojantiems vadovams, nei tiems vadovams, su kuriais anksčiau dirbo ${ }^{\prime 77}$. Apie tai VSD esą žinojo dar tuomet, kai A. Pocius buvo pakviestas dirbti šioje struktūroje. Be to, apie A. Pociaus priklausymą KGB rezervui esą jau buvo skelbta viešai. Parlamento vadovas priminė, kad pernai, prieš skiriant pareigūną VSD generaliniu direktoriumi, spaudoje pasirode publikacija, kurioje atskleistas šis jo biografijos faktas. Tuomet ši medžiaga buvo patikrinta ir pristatyta laikinai Prezidento pareigas ëjusiam A. Paulauskui. „,Mes nemanėme, kad tai yra svarbi aplinkybė jo gyvenime ${ }^{\iota 78}$, - sakè Parlamento vadovas. Tiesa, prieš skirdamas A. Pocių VSD direktoriumi, A. Paulauskas teigè neturëjęs informacijos, kad šis pareigūnas buvo įtrauktas ị KGB rezervinių karininkų sąrašus (bet laikinoji komisija neturëjo igaliojimų aiškintis ,"žinojimo-nežinojimo“ faktų).

Aiškumas ir besąlygiškas viešumas skiriant į atsakingas pareigas buvo eliminuotas. Apie atsakingu pareigūnų buvusius kontaktus (nesvarbu, kaip jie patys juos vertino) su KGB reikejjo paskelbti viešai dar prieš juos paskiriant i postus. Net jei būti įrašytam į KGB rezervą pagal Lietuvos įstatymus nẻra traktuojama kaip „,slaptas ir sąmoningas,, bendradarbiavimas su Sovietų Sajungos slaptosiomis tarnybomis ${ }^{79}$. Ministras A. Valionis patikino, jog tiek 1994 m., kai buvo skiriamas ambasadoriumi Varšuvoje, tiek 2000 m., kai buvo pirmą kartą skiriamas ministru, savo praeities nenuslèpé $\dot{e}^{80}$. Jis teigè ir 1994 m., prieš tapda-

\footnotetext{
${ }^{75}$ Gorienè G., (note 38).

76 Barkauskaitė O., "A.Pocius: mano byla buvo falsifikuojama", www.delfi.lt - Lietuvos radijas, 17022005

77 „Valstybės vadovams buvo žinoma apie A. Valionio ir A. Pociaus priklausymą KGB rezervui", www.delfi.lt, 07012005.

78 Ten pat.

79 ,UR ministras ir valstybės saugumo šefas turi pereiti liustracijos rentgeną, teigia liberalcentristai", Lietuvos rytas, $2005 \mathrm{~m}$. sausio $10 \mathrm{~d}$.

${ }^{80}$ Olekas J., (note 63).
} 
mas Lietuvos ambasadoriumi Lenkijoje, ir 2000 m., prieš paskiriamas Užsienio reikalų ministru, konsultavęsis, ar šis jo biografijos faktas gali turèti „,kokių nors teisiniu, etiniu ir kitokiu problemu“. ",Man buvo atsakyta, kad tai nelaikoma bendradarbiavimu. Valstybės vadovai apie tai žinojo, buvo informuoti ${ }^{\prime \prime 1},-$ pabrèžè Lietuvos diplomatijos vadovas. Jis tikino apie priklausymą KGB rezervui prisipažinęs net Prezidentui Valdui Adamkui.

Prezidentas V. Adamkus patikino šio fakto nežinojęs, vèliau patikslino, kad A. Valionis ministru buvo skiriamas prieš kelerius metus, todèl dabar visko gerai nepamenąs ${ }^{82}$. Per apkaltą nušalintasis Prezidentas Liberalų demokratu partijos pirmininkas R. Paksas reiškia didelę nuostabą, kad, jam būnant Ministru Pirmininku ir Lietuvos Prezidentu, nei Seimo Pirmininkas, nei kiti atsakingi pareigūnai nesuteikẻ informacijos apie A. Valionio ir A. Pociaus ryšius su KGB ${ }^{83}$. Jau Seime prasidejjus tyrimui aiškèjo, kad „žinojimo-nežinojimo“ problema aktuali ir teisejjams. Aukščiausiojo Teismo pirmininkas ir Teismų tarybos vadovas Vytautas Greičius teigè, kad „,KGB rezervo sąrašuose minimos trys teisèju pavardès, kurie ten pateko norėdami išvengti nuolatinių kvietimu i karinius apmokymus ${ }^{\text {"84 }}$. Parlamentinei komisijai netiriant šių aplinkybių tikslaus atsakymo su įrodymais apie „žinojimą-nežinojimą" nesulaukta.

Buvęs Valstybės saugumo departamento (VSD) vadovas dabartinis Lietuvos ambasadorius Ispanijoje M. Laurinkus teigè, kad keista tai, jog šiuo metu „yra susikoncentruota ties žmonėmis, kurie yra pademonstravę Lietuvai labai nuoširdų ir efektyvų darbą ${ }^{85}$. [...] Tai pažeminimas tų žmonių ir tokiu pagrindu, kuris Lietuvos saugumo požiūriu neturi jokios prasmès ${ }^{486}$. M. Laurinkus teigé buvęs informuotas ir apie A. Pociaus, ir apie A. Valionio priklausymą KGB rezervui bei „,apie Pociaus įtraukimą į KGB rezervą neaiškiomis aplinkybemis “ ${ }^{487}$ informavęs tuometinį Prezidentą V.Adamku, o vèliau - skiriant A. Pocių VSD vadovu - ir laikinai ejjusį Prezidento pareigas A. Paulauską. Kaip buvęs VSD direktorius, jis dar kartą patvirtino, kad buvimo KGB rezerve, kaip ir galimo informacijos apie tai buvimo svetimos valstybės specialiujų tarnybų rankose, nelaikè ir nelaiko grèsme nacionaliniam saugumui.

Bendra KGB rezervo vertinimo tendencija iki paviešinimo buvo ta, kad buvo laikomasi „,riebaus brūkšnio“ tarp praeities ir dabarties politikos. Atrodè, kad praeitị įmanoma užmiršti jos neįvertinus. Valstybės vadovai ir kai kurie kiti įtakingi politikai aiškino, esą įtraukimas į KGB rezervą neturëjęs didelès reikšmès, tai buvęs tartum gyvenimo aplinkybiu padiktuotas formalumas, joks nusikaltimas, jis nekẻlè grèsmės mūsų valstybei ir nelygintinas su sąmoningu bendradarbiavimu, o kadaise su KGB rezervu susaistyti - šiuo metu labai nusipel-

\footnotetext{
${ }^{81}$ Note 82.

${ }^{82}$ Olekas J., (note 63).

${ }^{83}$ Note 71

${ }^{84}$ KGB rezervininkų sąraše buvo minimi Kauno miesto apylinkẻs teismo pirmininko pavaduotojas, Teismu tarybos narys Edmundas Inokaitis ir Klaipèdos apygardos teismo Baudžiamujų bylu skyriaus teisejjas Valentinas Janonis. Žr.: ELTA, V.Greičius: du teisejjai patys prašési i KGB rezerva, $2005 \mathrm{~m}$.vasario $21 \mathrm{~d}$.

${ }^{85}$ BNS, UR ministras ir VSD vadovas darbais ịrode lojaluma Lietuvai, 2005 m. sausio $8 \mathrm{~d}$.

${ }^{86}$ Ten pat.

${ }^{87}$ Ten pat.
} 
nę Lietuvai žmonès. Pagal dabartinius ịstatymus tie žmonès nelaikytini jokiais pažeidèjais, nors žinoma, kad įstatymai ir buvo kuriami su didelèmis išlygomis, dažniausiai pasirenkant kompromisinius variantus. Tokias nuostatas buvo galima vertinti ir kaip aiškią politiką praeities (atminties) atžvilgiu, ir kaip kolektyvinès amnezijos išraišką.

Galima reziumuoti, kad ir A. Valionis, ir A. Pocius į valstybinius postus buvo paskirti nutylint arba nuslepiant nuo visuomenés ir netgi Seimo buvusią ju priklausomybę KGB karininkų rezervui. Priklausymas KGB karininkų rezervui nebuvo laikomas rimtu dalyku ir todèl manyta, kad pakanka apie tai žinoti tik keliems į pareigas skiriantiems valstybès pareigūnams.

"Patikrinto lojalumo“ aspektai buvo siejami su "rezervistų skandalo" įtaka Lietuvos tarptautinėms pozicijoms. Nors būti įrašytam į KGB rezervą pagal Lietuvos įstatymus nėa traktuojama kaip „slaptas ir sąmoningas“ bendradarbiavimas su Sovietų Sajungos slaptosiomis tarnybomis, A. Valionio nuomone, bendradarbiavimo su KGB šešèliai ,"gali būti politinio žaidimo dalis susilpninti mūsų derybines pozicijas su Rusija“. Seimo Pirmininkas A. Paulauskas pareiškè, jog iki šiol santykiuose su Rusija A. Valionis užèmè „aiškią ir principingą poziciją" ir pademonstravo, jog jam yra svarbūs "Lietuvos interesai" ${ }^{\text {" }} 8$.

İdomu tai, kad rusofobija ir totalinio sekimo „paranoja“ nepasižymëjęs dienraštis „,Lietuvos rytas“ ",rezervistų skandalą" įvertino kaip Rusijos specialiųjų tarnybu „, sėkmingiausią dešimtmečio operaciją Lietuvoje ${ }^{89}$ arba manipuliaciją viešaja nuomone ${ }^{\prime \prime 90}$. Visiškai suprantama, kad Rusijos specialiosios tarnybos siekè ir siekia prasiskverbti ị svarbiausias valstybès institucijas, Ginkluotąsias pajėgas, partijas, su NATO ir Europos Sajunga susijusias struktūras aktyvindamos savo veiklą ir didindamos pajègumą Lietuvoje ${ }^{91}$. Po Lietuvai tekusio vaidmens Oranžinės revoliucijos metu Rusijos pozicijų stiprinimas Lietuvoje buvo prognozuotas. Pasak prancūzų dienraščio „,Le Figaro“, , ,Rusijai, kurios santykiai su Lietuva visada buvo įtempti, gali būti svarbu skatinti nesutarimus ${ }^{\prime \prime 22}$. Valstybės saugumo departamento (VSD) generalinis direktorius A. Pocius pareiškè,jog „egzistuoja tam tikros specialiujų tarnybu veiklos kryptys, pagal kurias veikiant stengiamasi, kad Lietuvos narystė ES ir NATO nebūtų visavertè. Bandoma siekti, kad mūsų šalis taptų tarsi nereikšminga tarptautinių organizacijų nare ${ }^{\mu 93}$. Bet vienareikšmiam atsakymui, kad šioje istorijoje ne paskutiniuoju smuiku griežia Rusijos specialiosios tarnybos, patvirtinančių faktų nebuvo. Greičiau priešingaiRusijos specialiosios tarnybos, tebenaudojančios kai kuriuos KGB metodus, tebesinaudojančios KGB palikimu, nekomentavo vykusio skandalo ir greičiausiai rèmėsi tomis galimybèmis, kurias teikè likusios KGB archyvų dalies turëjimas ir Lietuvoje įsisiūbavęs vidaus politinis skandalas.

88 Ten pat.

89 Vasiliauskas V., (note 12)

${ }^{90}$ Vainauskienė B., "KGB šmėklos atsisako atostogauti", Lietuvos rytas, 2005 m. sausio 10 d.

91 Jakilaitis E., ,Slapti Maskvos čiuptuvai nepaleidžia Lietuvos“, Lietuvos rytas, $2005 \mathrm{~m}$. sausio $13 \mathrm{~d}$

${ }_{92}$ ELTA, "Le Figaro": praeitis nepaleidžia Lietuvos politiku“, 2005 m. sausio mèn. 20 d.

93 „VSD pastebi padidèjusį kai kurių valstybių spectarnybų dèmesį Lietuvos reikalams", Lietuvos Rytas-BNS, 2005 m. sausio 13 d. 


\section{Laikinoji tyrimo komisija ir jos išvados}

\subsection{Komisijos sudarymas ir jos tikslų formulavimas}

Lietuvos Respublikos Seimo 2005 m. sausio 20 d. nutarimu Nr. X-98 (Žin., 2005, Nr. 12-365) suformuota laikinoji komisija Seimo Pirmininko pavaduotojo A. Pekeliūno, Valstybės saugumo departamento generalinio direktoriaus A. Pociaus ir Užsienio reikalų ministro A. Valionio buvimo SSSR valstybės saugumo komiteto rezervo sąrašuose faktams ir aplinkybėms ištirti. Jos pirmininku patvirtintas Darbo partijos narys Skirmantas Pabedinskas. Komisija ịpareigota įvertinti KGB atsargos karininkų statusa, nustatyti, kokiomis aplinkybèmis minèti trys pareigūnai buvo įtraukti į sovietų saugumo rezervo sąrašus, ar skiriant juos i šiuo metu einamas pareigas nebuvo pažeisti teisės aktai, ar ju buvimas dabartinėse pareigose nekelia grèsmès nacionalinio saugumo interesams ir ar į KGB rezervo sąrašus buvo įtraukti kiti dabartiniai politikai, teisëjai ar valstybės pareigūnai ${ }^{94}$. Taip pat komisija turëjo nustatyti, ar buvimas KGB rezerve yra prilygintinas sąmoningam bendradarbiavimui, kuris vertinamas griežčiau, numatant apribojimus eiti pareigas valstybès tarnyboje. Komisijos pirmininko pavaduotojas Rimantas Dagys pažymëjo, kad KGB rezervistų veikla tam tikrais atvejais galëjo kelti grèsmę, bet ,kiekvienas atvejis turi būti nagrinejjimas kaip konkretus ${ }^{495}$. Jei KGB rezervą tirianti Seimo laikinoji komisija konstatuotu, jog sutikimas būti įrašytam į KGB rezervą yra tolygus sąmoningam bendradarbiavimui su sovietine specialiaja tarnyba, tai turètu , „labai rimtu pasekmiü. Parlamentinei laikinajai komisijai patvirtinus sąmoningo bendradarbiavimo faktą, KGB rezerve buvusiems Seimo nariams grèstų mandatų atėmimas. Tačiau, anot Vyriausiosios rinkiminės komisijos (toliau - VRK) nario, sąmoningo bendradarbiavimo faktą dar turètų patvirtinti Liustracijos komisija arba teismas. Liustracijos komisijai arba teismui pripažinus sąmoningo bendradarbiavimo faktą, VRK tektų pripažinti, jog pildydami kandidato į Seimo narius anketą jie nuslèpé šį faktą. Seimo pirmininko pavaduotojas A. Pekeliūnas bei Užsienio reikalų ministras A. Valionis kandidatuodami į Seimą anketoje nebuvo nenurodę, jog ne pagal Lietuvos valstybės užduotis buvo sąmoningai bendradarbiavę su kitų valstybių specialiosiomis tarnybomis ${ }^{96}$.

Bet Liustracijos komisijai priklausymo KGB rezervui neįvertinus kaip sąmoningo bendradarbiavimo, Vyriausioji rinkimų komisija išnagrinëjo Tẻvynės sajungos frakcijos nario Sauliaus Pečeliūno prašymą ${ }^{97}$ dẻl $1991 \mathrm{~m}$. įstatymo

\footnotetext{
${ }_{94}$ BNS, Seimas patvirtino laikinosios komisijos pareigūnu ryšiams su KGB ištirti sudèti, 2005 m. sausio $21 \mathrm{~d}$. Suformuluoti laikinosios komisijos tikslai: Koks yra KGB rezervo ir i KGB rezervo sąrašus įtrauktų asmenų statusas: kokias funkcijas vykdė KGB rezervas, kokia tvarka asmenys buvo įtraukiami į šiuos sąrašus, kokią įtaką toks įtraukimas turejjo ir turi ju pareigoms? Kokiomis aplinkybėmis Alfredas Pekeliūnas, Arvydas Pocius ir Antanas Valionis buvo įtraukti i KGB rezervo sąrašus? Ar į KGB rezervo sąrašus yra įtraukta kitų šiuo metu valstybės politiku, teisejjuc ar valstybės pareigūnų pareigas einančių asmenų?

95 ,"Liustracijos komisija ketina iš naujo įvertinti priklausymą KGB rezervui“, www.delfi.lt, 04 022005.

${ }^{96} \mathrm{BNS}$, I KGB rezervq savo noru patekę parlamentarai gali likti be mandatu, $2005 \mathrm{~m}$. vasario $3 \mathrm{~d}$.

${ }_{97} \mathrm{BNS}$, A. Valionis ir A. Pekeliūnas nepažeide Seimo rinkimu isstatymo, $2005 \mathrm{~m}$. vasario $3 \mathrm{~d}$.
} 
taikymo. S. Pečeliūnas siūlè remtis $1991 \mathrm{~m}$. pabaigoje įsigaliojusiu ịstatymu „Dèl deputatu, įtariamų sąmoningu bendradarbiavimu su kitų valstybiu specialiosiomis tarnybomis, mandatu patikrinimo". Šiame įstatyme buvo nurodyta, kad „,bendradarbiavimo" sąvoka apima asmens įtraukimą į KGB (MGB) ar kitų specialiujų tarnybų sąrašus ar užverbavimą rezidentu, agentu, igaliotiniu, patikètiniu ar informatoriumi ir jo atitinkamos veiklos įrodymus; kitokią sąmoningą ir sistemingą (du ir daugiau kartų) veiklą - žinių KGB ar kitoms specialiosioms tarnyboms teikimą, užduočių davimą ar vykdymą ir t. t. ${ }^{98}$ VRK pareiškė negalinti nustatyti fakto, ar šie parlamentarai sovietmečiu bendradarbiavo su KGB ar kitomis specialiosiomis tarnybomis, nes tai yra teismo kompetencija. VRK nariai konstatavo neturintys ir negalintys gauti dokumentu, kurie įstatymų nustatyta tvarka patvirtintu juridinį faktą, kad A. Valionis ir A. Pekeliūnas bendradarbiavo su kitų valstybių specialiosiomis struktūromis. „,Saugumas buvo užklaustas, bendradarbiavimo nepatvirtino, vadinasi, kandidatai buvo registruoti teisètai. Bet net jei dabar šis faktas pasitvirtintu, įstatymas nesuteiktu teisės VRK atimti mandatą“, - teigė komisijos narys Viktoras Rinkevičius. „Pripažinimas, kad priklausẻ rezervui, nèra pripažinimas, kad sąmoningai bendradarbiavo ${ }^{\prime 99}$, - pažymëjo VRK nariai.

KGB rezervo bylos buvo sudarytos remiantis tuometinėmis instrukcijomis, kuriose svarbiausi buvo asmeniniai KGB karininkų kontaktai su potencialiu KGB atsargos karininku - sutikimo priklausyti šiam rezervui gavimas ir patikimumo patvirtinimas. Užsienio reikalų ministras A. Valionis ir Valstybės saugumo departamento direktorius A. Pocius Seimo laikinajai tyrimo komisijai perduotuose paaiškinimuose pripažino, kad sovietmečiu priklausė KGB rezervui. Anot A. Valionio, ,LSSR KGB man pateikè jau užpildytą anketą [...] ir informavo, kad esu įrašytas ị KGB atsargos karininkų rezervą. [...] Protestuoti prieš tokį sprendimą galimybių nemačiau, nes manęs niekas neprašè sutikimo pervesti į KGB atsargos karininkų rezervą ${ }^{\prime 100}$ [iš SSSR Ginkluotujų pajègų atsargos karininkų-A.A.].

Laikinajai parlamentinei komisijai, tiriančiai aukštų pareigūnų sąsajas su KGB, liudijęs Valstybės saugumo departamento (VSD) vadovas A. Pocius, atsakydamas i papildomai iškilusius klausimus, teigè, kad „,mano byloje yra daugybe neatitikimu, o byla buvo kurpiama man už nugaros. [...] Vienintelis dokumentas, patvirtinantis mano sutikimą, - tik kažkam susidaręs įspūdis, jog sutinku“"101. Pociaus teigimu, su savo byla jis susipažino prieš ateidamas dirbti i VSD ${ }^{102}$.

Pirmiausia komisijos nariai tikëjosi gauti oficialų visų KGB rezervistu sąrašą. Sąrašo buvo prašoma iš VSD, tarpžinybinès Liustracijos komisijos bei Lietuvos gyventoju genocido ir rezistencijos tyrimo centro (toliau - LGGRTC). Jei būtu paaiškèję, kad rezervo sąraše yra ir daugiau aukštus postus užimančiu

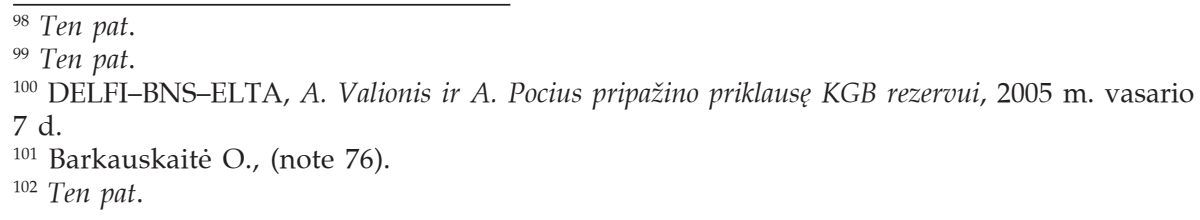


pareigūnu, jie, anot komisijos pirmininko S. Pabedinsko, bus paviešinti. Tikètasi sužinoti, ar įrašyti į KGB rezervo sąrašus duodavo sutikimą raštu tokiam įrašui, ar jie įsipareigodavo atlikti kokias nors sovietinio saugumo užduotis, už ką buvo skatinami. Komisijos nariai tikèjosi sužinoti, ar asmenys turëjo slèpti informaciją apie savo buvimą rezerve, ar buvo asmenu, atsisakiusių būti įrašyti į rezervą, ar atkūrus Lietuvos nepriklausomybę jie tęsè savo veiklą ir kieno nurodymu veiké: pareigūnu, kurie gyveno ir dirbo Lietuvoje, ar nurodymus gaudavo iš Maskvos. Komisija kiekvienos iš instituciju prašo pateikti savo nuomonę apie tai, koks turi būti nustatytas apsaugos mechanizmas rezervo sąrašuose esantiems asmenims. Tuo metu įstatymas neįpareigojo KGB rezervistų kreiptis į specialią Liustracijos komisiją. Iš pastarosios pareikalauta ataskaitos, kaip iki šiol buvo vykdomas $2000 \mathrm{~m}$. įsigaliojęs Liustracijos įstatymas ${ }^{103}$.

Po gautų atsakymų suabejoję šalies istorikų objektyvumu, Seimo laikinosios tyrimo komisijos nariai pasiūlè paprašyti KGB rezervo veiklos įvertinimo iš Rusijos [t. y. faktiškai iš Federalinès saugumo tarnybos, kurios žinioje buvo likusieji KGB archyvai - A.A.]. Šios iniciatyvos autorius liberalcentristas Raimundas Šukys teigia, kad šitaip bandoma išnaudoti visus informacijos šaltinius. „Lietuvos gyventoju genocido ir rezistencijos tyrimo centro (LGGRTC) atstovai turi kategorišką nuomonę“ ", - savo pasiūlymo motyvus aiškino R. Šukys. Po išsakytos kritikos, kad „prašymas Maskvai įvertinti KGB rezervo veiklą pakenktų Lietuvos institucijų, pirmiausia - Seimo, autoritetui“, tokio siūlymo atsisakyta. Galiausiai nuspręsta palikti pačiai Užsienio reikalų ministerijai atsakyti, i kurias valstybes reikètų kreiptis dèl informacijos apie KGB rezervo veik$\mathrm{lac}^{104}$. Komisija nusprendè informacijos prašyti Mykolo Riomerio universiteto Operatyvinès veiklos katedros vedejo Kęstučio Šimkaus (Prezidento V. Adamkaus patarejo organizuoto nusikalstamumo ir korupcijos prevencijos klausimais $)^{105}$. Oficialiai dèl papildomos informacijos nesikreipta net i artimiausią kaimynę Latviją, kurios archyvuose išliko, ko gero, išsamiausia KGB veiklą reglamentavusių normatyvinių aktų bazè.

\subsection{Komisijos išvados: KGB rezervas ,Iygu“ karinei prievolei}

Komisija $2005 \mathrm{~m}$. sausio 28 d. - vasario 28 d. posėdžių metu nustatė, kad, nagrinëjant klausimą dèl KGB rezervo ir į KGB rezervo sąrašus įtrauktų asmenu statuso, reikètų atkreipti dėmesị i Lietuvos Respublikos įstatymuose ir kituose teisès aktuose neapibrěžiamą nei KGB rezervo, nei į KGB rezervo sąrašus įtrauktų asmenų statusą. İtraukimas į KGB rezervą įtakos darbinei ar tarnybinei veiklai neturejo, nes jokių įsipareigojimu, pasižadëjimų ir pan. nebuvo [nors nieko nesakoma, kaip vertinti sutikimą būti KGB rezerve-A.A.]. Atitinkamos pareigos atsirastų tik prasidejjus karui. Buvimas KGB rezerve turètų būti prilyginamas

\footnotetext{
103 "Gudavičius S., KGB verpete - naujos pavardès", Kauno diena, 2005 m. sausio 29 d.

104 "Seime klaidžioja neoficialus KGB rezervo sąrašas", www.delfi.lt, 29012005.

105 BNS, (note 97).
} 
karinès prievolès atlikimui (tokiai išvadai padaryti pasinaudota doc. Šimkaus 2005 m. vasario 11 d. raštu komisijai). Bet liko nepaaiškinta, kodèl už vengimą atlikti privalomą karinę tarnybą sovietinëje armijoje buvo numatyta baudžiamoji atsakomybė, o už atsisakymą būti KGB atsargos karininku nebuvo numatyta jokių sankcijų. Kita vertus, liko neivvertinta ir tai, kad tarnyba (arba darbas) KGB struktūrose taip pat buvo prilyginta tarnybai Ginkluotosiose pajėgose.

Komisija padarè išvadą:

„,SSSR KGB rezervas buvo KGB mobilizacinė dalis, skirta ypatingojo periodo (karo grėsmės, karo pradžios, stichinių nelaimių ir masinių riaušių metu) ir karo atvejams. [...] Komisija neturi tikslių duomenu, ar įrašymas į KGB rezervo sąrašus turëjo įtakos įtraukiamų asmenų pareigoms (bet nekomentuojama ar padëjo daryti karjerą tuometinëje komunistinëje nomenklatūroje - A.A.). Asmenys sutikdavo būti įrašyti į KGB rezervą dèl ịvairių motyvų: dèl karjeros galimybès, siekiant išvengti karinès tarnybos. Komisijos duomenimis, atsisakymas būti įrašytam į KGB rezervą jokių pasekmių nesukeldavo “"106.

Remdamasi turimais duomenimis, komisija padarè išvadą, kad A. Pocius buvo įtrauktas i̊ KGB karininkų rezervo sąrašą, tačiau komisijai nepakako duomenų pateikti išvadą, ar jam apie tai buvo žinoma. Komisija nusprendè, kad A. Valionis buvo įtrauktas į KGB rezervą, apie ką vèliau jis buvo informuotas. Ar nebuvo pažeista teisès aktuose nustatyta skyrimo i pareigas tvarka skiriant minètus asmenis į šiuo metu einamas pareigas, komisijos išvadose teigiama: įrašymo i Valstybės saugumo komiteto (KGB) kaip specialiosios tarnybos rezervo sąrašus fakto neužtenka pripažinti, kad asmuo faktiškai bendradarbiavo su specialiosiomis tarnybomis. Be to, be objektyvaus slapto bendradarbiavimo su specialiosiomis tarnybomis požymio - faktiško užduočių ar pavedimų vykdymo, būtinas ir subjektyvusis požymis, t. y. asmuo, vykdydamas pavedimus ir užduotis, turi veikti sąmoningai pagal rašytinį arba nerašytinu įsipareigojimą. Taigi asmuo, vykdydamas specialiuju tarnybų pavedimus, turëjo sąmoningai žinoti, kieno užduotis ir pavedimus jis vykdo. Atsižvelgdama į tai, komisija padare išvadą, kad, skiriant A. Valionį į Užsienio reikalų ministro pareigas ir A. Pocių i Valstybės saugumo departamento generalinio direktoriaus pareigas, Lietuvos Respublikos teisės aktuose įtvirtinti reikalavimai nebuvo pažeisti.

Komisija neturëjo duomenu, patvirtinančiu, kad A. Valionis, A. Pocius ar A. Pekeliūnas vykdè kokias nors užduotis ar pavedimus ar kokiu nors būdu buvo ịsipareigoję atlikti juos ateityje. Pasak komisijos, tai suponuoja minti, kad nè vienas iš minètu asmenų neprivalëjo prisipažinti apie ju įrašymo į KGB rezervo sąrašus faktą.

Bet vienas prieštaringiausiu (teisiniu požiūriu) komisijos sprendimų buvo dèl Lietuvos Respublikos ịstatymo „Dẻl deputatu, įtariamų sąmoningu bendradarbiavimu su kitų valstybių specialiosiomis tarnybomis, mandatu patikrinimo“ taikymo. Komisija nusprendè, kad, atsižvelgiant ị įstatymo prièmimo aplinkybes bei turini, jis faktiškai nebegali būti taikomas:

\footnotetext{
106 „Laikinosios komisijos Lietuvos Respublikos Seimo Pirmininko pavaduotojo Alfredo Pekeliūno, Valstybės saugumo departamento generalinio direktoriaus Arvydo Pociaus ir Užsienio reikalu ministro Antano Valionio buvimo SSSR Valstybès saugumo komiteto rezervo sąrašuose faktams ir aplinkybėms ištirti išvados“, 2005 m. kovo 1 d., http://www3.lrs.lt/
} 
,"[...] analogiškos [bet ne visos - A.A.] minèto įstatymo nuostatoms normos yra įtvirtintos $1999 \mathrm{~m}$. priimtame specialiajame Lietuvos Respublikos asmenu, slapta bendradarbiavusiu su buvusios SSSR specialiosiomis tarnybomis, registracijos, prisipažinimo, įskaitos ir prisipažinusiujų apsaugos įstatyme. Minètas įstatymas taikomas ne tik Seimo nariams, tačiau ir kitiems valstybės pareigūnams, tarnautojams bei asmenims, dirbantiems valstybės institucijose ir ịstaigose. Todẻl iškilus slapto Seimo narių bendradarbiavimo su buvusios SSSR slaptosiomis tarnybomis faktui, turètų būti taikomas ne nebeatitinkantis susiklosčiusių dabartinių visuomeniniu teisiniu santykiu įstatymas “ ${ }^{\prime 107}$.

Atsižvelgdama į tai, komisija priejo išvadą, kad įstatymuose nustatyta atsakomybė už nepranešimą Lietuvos valstybei apie slapto bendradarbiavimo su buvusios SSSR slaptosiomis tarnybomis faktą nei A. Valioniui, nei A. Pociui, nei A. Pekeliūnui negali būti taikoma.

Pagal Nacionalinio saugumo pagrindų ịstatymą vienas svarbiausių nacionalinio saugumo objektu yra žmogaus ir piliečio teisès, laisvės bei asmens saugumas. Tai apima ir asmens saugumą nuo jo veiksmų laisvès varžymo grasinant paviešinti ji kompromituojančius duomenis. Pagal Nacionalinio saugumo pagrindų įstatymą valstybės valdžia privalo apsaugoti Lietuvą nuo užsienio valstybių slaptujų tarnybų ardomosios veiklos. Šiai veiklai būdingas tradicinių ir netradicinių metodų bei nauju technologijų panaudojimas siekiant neteisètai gauti informaciją, destruktyviai veikti ir daryti įtaką kariniams pajègumams, politiniams procesams ir kitoms socialinio bei ekonominio gyvenimo sritims. Komija nutarè, kad, kadangi Seimas, Užsienio reikalų ministerija ir Valstybės saugumo departamentas vykdo itin svarbias funkcijas užtikrinant nacionalinį saugumą, o neteisėtai varžant šių institucijų vadovų veiksmų laisvę grasinant paviešinti juos kompromituojančius duomenis gali būti daroma įtaka ir šių institucijų veiklai. Todèl, atsižvelgiant į šiu institucijų vykdomų funkcijų svarbą, taip gali būti keliama grėsmė nacionaliniam saugumui.

Atkūrus Lietuvos Respublikos nepriklausomybę, KGB ne kartą Lietuvos teisès aktuose îvertinta kaip represine okupacinès valdžios institucija. Todèl asmens priklausymas KGB rezervui visuomenëje galëjo būti vertinamas neigiamai, kaip asmens garbę ir orumą žeminanti aplinkybė. Dèl to grasinant paviešinti duomenis apie Seimo, Užsienio reikalų ministerijos ir Valstybės saugumo departamento vadovų priklausomybę KGB rezervui galëjo būti neteisėtai varžoma jų veiksmų laisvė ir, taip pat veikiant užsienio specialiosioms tarnyboms, galètų būti keliama grèsmè nacionaliniam saugumui. Kita vertus, komisijai nustačius, kad A. Pocius ir A. Valionis priklause KGB rezervui, šie duomenys tapo vieši [nors jie tapo vieši ne dèl komisijos veikos - A.A.], todèl nèra galimybès varžyti šių asmenų laisvę aptartu būdu. Ir komisija patvirtino, kad A. Pociaus ir A. Valionio dabartiniu pareigų atlikimas nekelia grèsmės nacionalinio saugumo interesams.

Išnagrinèjusi ir įvertinusi pateiktus dokumentus, komisija priëjo išvadą, kad kai kurie į SSSR KGB rezervo sąrašus įtraukti asmenys šiuo metu užima

${ }^{107}$ Ten pat. 
valstybės politiku, teisëjų ar valstybės pareigūnų pareigas. Komisija Seimui siūlo parengti ir priimti teisès aktus, reglamentuojančius asmenu, įtrauktų į KGB rezervo sąrašus, paviešinimo tvarką ir sąlygas ${ }^{108}$.

KGB rezervo veiklą tyrusiai Seimo laikinajai komisijai patvirtinus savo tyrimo išvadą ir konstatavus, jog KGB rezervas buvo sovietų saugumo mobilizacinė dalis, o tai, kad jai priklausė aukšti šalies pareigūnai, nekelia grėsmės nacionaliniam saugumui, išvadas kritiškai îvertino Liberalų ir centro sajunga. Politikų manymu, aukštu pareigūnų sąsajas su KGB tyrusi komisija nepaskelbė nieko nauja, o jos išvados pavèluotos ir nesprendžia KGB problemos iš esmès ${ }^{109}$. Liberalcentristų ịsitikinimu, reikètu grižti prie anksčiau siūlytos idejjos reformuoti KGB rezervistų veiklą nagrinëjusią laikinają tyrimo komisiją, paverčiant ją nuolat veikiančia institucija. Naujai suformuota ir išplėsta komisija turètų iki šio Seimo kadencijos pabaigos baigti Lietuvos dekagèbizaciją - susipažinti, išnagrinèti bei oficialiai paskelbti visą turimą informaciją apie Lietuvoje veikusias sovietų represines struktūras ir jos bendradarbius. Liberalcentristų įsitikinimu, tik sisteminis, nuolatinis, viską apimantis sovietų represinių struktūru tyrimas leistų išvengti proginės raganų medžioklès ir pagaliau palaidotų daugiau negu dešimtmeti po šalį tebeklaidžiojančią KGB šmèklą ${ }^{110}$.

\subsection{Viešosios nuomonès ir politinio elito pozicijụ išsiskyrimas}

Socialinių tyrimų institute atliktame tyrime buvo tiriami „paprastų žmonių" - Lietuvos kaimų ir miestelių vyresniosios kartos, pergyvenusios visą sovietmetị, požiūris į sovietinę praeitį. Dauguma apklaustuju pasisakè už „,tiesos sakymo" strategiją: praeitis turi būti įvardyta ir ịvertinta iš dabarties pozicijų. Tos pačios pozicijos laikèsi ir dauguma sovietinio režimo aukų - buvę politiniai kaliniai ir tremtiniai. Juos patenkintu, ju žodžiais, "teisybès“ igyvendinimas, išreikštas simbolinėmis formomis: atsakinguju - komunistinio režimo nusikaltimų organizatorių ir vykdytojų - îvardijimas bei ịvertinimas, pageidautinas ir viešas atsakingujų atsiprašymas. Šią žmoniu grupę ypač žeidžia atsakomybės reliatyvizavimo plitimas valdžios institucijose ir oficialiajame diskurse, kai kuriuos - ir aukštos „,buvusiujų“ užimamos pozicijos, sąžiningai neįvertinus savo bendradarbiavimo su sovietiniu režimu.

Dar iki Seimo laikinosios komisijos sprendimo priemimo buvo įvertintas Lietuvos gyventojų požiūris į asmenis, įrašytus į KGB rezervą. Dauguma Lietuvos gyventojų manè, kad sovietmečiu į KGB rezervą įrašyti asmenys neturètu užimti aukštu valstybiniu postų. Tai rode sociologinè apklausa, kurią naujienu agentūros BNS užsakymu atliko Rinkos analizès ir tyrimu grupè (RAIT). Paklausti, ar KGB rezerve praeityje buvę asmenys turi moralinę teisę užimti aukštus valstybinius postus, $63,3 \%$ respondentų atsakè neigiamai; $28,6 \%$ teigè ma-

\footnotetext{
${ }^{108}$ Komisija tyrimo rezultatu išvadą patvirtino $2005 \mathrm{~m}$. kovo $1 \mathrm{~d}$. posėdyje. Balsavimo rezultatai: „už“ -9 , „prieš -1 , ,susilaikè

109 „KGB rezervą narsto ir politikai, ir dvasininkai“, Lietuvos rytas, 2005 m. kovo 7 d.

${ }^{110}$ Ten pat.
} 
nantys, jog jie tokią moralinę teisę turi; 8,1 \% respondentų i šç klausimą neatsakè. Neigiamai apie buvusių KGB rezervistų likimą aukštuose postuose dažniau atsiliepé vyrai (66,1\%), 30-49 ir 70-74 metu grupiu $(68,5 \%)$, rajonu $(68,1 \%)$ ar apskričiu $(67,2 \%)$ centruose gyvenantys respondentai. Tolerantiškiau i buvusių rezervistu galimybes dirbti valstybès postuose atsiliepè 16-19 metu jaunimas $(33,3 \%)$ ir didžiuju miestu gyventojai $(57,8 \%)$ bei didesnes nei 600 litų pajamas vienam šeimos nariui per mènesi gaunantys respondentai ${ }^{111}$.

74 \% šalies gyventojų manė, kad buvo tikslinga paviešinti KGB rezervui priklausiusių žmonių pavardes; 13 \% laikosi priešingos nuomonės, o 14 \% šiuo klausimu neturëjo nuomonès, paaiškëjo DELFI užsakymu "Spinter tyrimams“ $2005 \mathrm{~m}$. vasario 3 - $12 \mathrm{~d}$. atlikus apklausą. Sąrašų paviešinimui labiau pritaré vyresnio amžiaus gyventojai, o štai jaunimas dažniau neturëjo aiškios nuomonès šiuo klausimu. Respondentai neišsakẻ aiškios nuomonès, kaip turètų būti pasielgta (ar turètų patys pasielgti) su KGB rezervo sąrašuose esančiais aukštais valstybès pareigūnais: $27 \%$ vertinimu, tokie žmonės privalo besąlygiškai atsistatydinti, didžiausia grupé - $38 \%$ mano, kad galimybè toliau eiti pareigas turètų būti vertinama pagal bendradarbiavimo su KGB lygi, 11 \% teigè, kad turi būti atsižvelgta ị šių asmenų nuopelnus Lietuvai jau po Nepriklausomybės atkūrimo. Lietuvos gyventojai nepritaria priëjimo prie KGB archyvinių dokumentų ribojimui $-80 \%$ apklaustujų tokius valdžios veiksmus vertina neigiamai. Itin neigiamai tokius ribojimus vertina vyresnès kartos atstovai, jaunesni respondentai dažniau susilaikè nuo vertinimo ${ }^{112}$. Galima teigti, kad vyraujanti viešoji nuomoné neatitiko aukščiausių šalies pareigūnų pozicijos skiriant į nacionaliniam saugumui svarbias pareigas į KGB rezervą įrašytus asmenis, nors viešojoje nuomoneje akivaizdūs ir atsiribojimo nuo praeities problemų sprendimo požymiai.

\section{Išvados}

XX a. 8-9 dešimtmečiais KGB iš anksto besirengiant spręsti „ypatingajam periodui" numatytus uždavinius, pasiruošus skubiems veiksmams taikos meto ekstremaliomis sąlygomis, buvo sudarytas „KGB atsargos karininkų rezervas", į kurị iš Ginkluotuju pajėgų atsargos buvo pervesta ne daugiau kaip 273 atsargos karininkų ir įtraukta ị KGB atsargos karininkų įskaitą. Atranka i KGB rezerva, patikimumo patikrinimas, sutikimo bendrauti su KGB išgavimas pakartojo etatinio KGB darbuotojo atrankos ir patikimumo patikrinimo procedūras. KGB atsargos karininku patikrintas lojalumas komunistinei sistemai, tinkamumas KGB uždaviniams igyvendinti, galëjo garantuoti spartesnį patekimą į komunistinę nomenklatūrą ar pareigų kilimą. Dẻl Lietuvos visuomenejje vyraujančio neigiamo požiūrio į KGB, bet kokie slapti ryšiai su šia komunistine slaptaja tarnyba iš anksto buvo vertinami kaip galintys sukelti grèsmes Lietu-

\footnotetext{
111 „Daugelis - prieš KGB rezervistų buvimą aukštuose postuose“, Lietuvos rytas, 2005 m. vasario $18 \mathrm{~d}$.

112 "Dauguma šalies gyventojų mano, kad KGB rezervistų pavardes paviešinti - tikslinga“, www.delfi.lt, 21022005.
} 
vos nacionaliniam saugumui. Šiuo atveju neigiamas visuomenès požiūris į santykius su KGB galëjo daryti įtaką ir URM, ir VSD vadovybès darbui bei galëjo netiesiogiai sukelti grèsmę nacionaliniam saugumui, destabilizuoti politinę situaciją arba padètį už nacionalinį saugumą atsakingose institucijose.

Politinių šalies sluoksnių (dèl dalies įstatymų leidžiamosios ir vykdomosios valdžios atstovų sąsajų su buvusia komunistine nomenklatūra, dẻl neįvykdytos desovietizacijos) santykis su praeities palikimu ir atmintimi ,,nuspalvintas" nekonstruktyvia daline amnezija ir reliatyvizavimu. Prasidejusi diskusija tik išryškino jau seniai egzistavusị aukščiausių politinių sluoksnių požiūrị i praeitį. Buvimas KGB rezerve, kaip ir galimas informacijos apie tai buvimas Rusijos specialiujų tarnybų rankose, nesietas su galimomis grèsmėmis nacionaliniam saugumui. Santykio su KGB permąstymas pasuktas parlamentinio tyrimo ir teisės aktu tobulinimo keliu. Ir nors paviešintoje aukštų valstybės pareigūnu, KGB rezervistu, praeityje, formaliai teisiškai žiūrint, neaptikta jokio ,,sąmoningo" bendradarbiavimo pédsaku, tačiau moraliniu požiūriu nemažai visuomenès daliai to ar kito asmens praeities susipynimas su represijų ir teroro organizacijos KGB veikla tebeliko sunkiai pateisinama.

Tam tikroje visuomenės dalyje egzistuoja poreikis susidoroti su savo praeitimi įvardijant tuos, kurie buvusio režimo vardu vykdè nusikaltimus, pažeidinëjo žmogaus teises arba buvo susiję su tai vykdžiusiomis struktūromis. Laikinoji Seimo komisija jokių grèsmių nacionaliniam saugumui dèl aukštu pareigūnu priklausymo KGB rezervui nesurado, nors tokia pozicija visiškai skyrėsi nuo sociologiniu apklausų metu nustatytos viešosios nuomonès. Tai rodo, kad „visuomenès sutartis“ šiuo klausimu dar nepasiekta.

Vilnius, 2005 m. rugsëjo $13 d$. 